\section{A) Check for updates}

Cite this: Nanoscale, 2020, 12 23444

Received 26th July 2020,

Accepted 20th October 2020

DOI: 10.1039/d0nr06820a

rsc.li/nanoscale

\title{
Halloysite nanotubes - the nano-bio interface
}

\begin{abstract}
Ofer Prinz Setter and Ester Segal (D) *
The numerous biological applications of nanoparticles in general and nano-clays in particular are rooted in understanding and harnessing their dynamic nano-bio interface. Among clays, the intrinsically-mesoporous halloysite nanotubes (HNTs) have emerged in recent years as promising nanomaterials. The diverse interactions of these nanotubes with living cells, encompassing electrostatic, van der Waals, and ion exchange, along with cellular response, are crucial in determining the behaviour of HNTs in biological systems. Thus, rational engineering of the nanotube properties allows for vast applications ranging from bacteria encapsulation for bioremediation, through algae flocculation for aquaculture, to intracellular drug delivery. This review summarizes the many aspects of the nano-bio interface of HNTs with different cell types (bacteria, algae and fungi, and mammalian cells), highlighting biocompatibility/bio-adverse properties, interaction mechanisms, and the latest cutting-edge technologies.
\end{abstract}

\section{Introduction}

The association of cells with solid particulate matter lies in the interdisciplinary boundary between nanotechnology, material science, and biology. ${ }^{1}$ An enlightening review by Fakhrullin et $a l^{2}$ describes various applications for these so-called "cyborg" cells, such as yeast functionalized with gold nanoparticles for microelectronics; ${ }^{3}$ fungi hyphae covered with platinum nanoparticles for biochemical catalysis; ${ }^{4}$ and magnetized mammalian cells for accurate tissue construction. ${ }^{5}$ The nano-bio interactions may be spontaneous and non-specific, directed by a targeting probe or externally induced through layer by layer coverage. ${ }^{2}$

Numerous emerging potential applications of clay particles, which are abundant and considered as environmentallyfriendly, ${ }^{6}$ rely on their intriguing nano-bio interface. ${ }^{7-10}$ For example, layered double hydroxides may serve as a platform for microbial fuel cells, bioremediation, intracellular drug delivery and antibacterial activity. ${ }^{11,12}$ Similarly, attapulgite (aka palygorskite), another nanoclay exhibiting a nanoporous morphology, is already approved as an excipient, and is further investigated for additional pharmaceutical applications. ${ }^{8,10}$

Halloysite (mostly regarded as halloysite nanotubes or HNTs) is a natural mineral clay composed of alternating layers of silica and alumina geologically rolled into mesoporous tubular particles (Fig. 1) which exhibit considerable adsorption and loading capabilities. ${ }^{13}$ Following current advancement in nanotechnology, the physiochemical properties of HNTs were thoroughly described, ${ }^{14}$ unveiling the potential of this material

Department of Biotechnology and Food Engineering, Technion - Israel Institute of Technology, Technion City, 3200003 Haifa, Israel. E-mail: esegal@technion.ac.il for vast applications, ranging from catalysis ${ }^{15}$ to biomedicine. ${ }^{16-19}$ HNTs abundancy combined with their perceived biocompatibility and the repertoire of available functionalization routes have led to an increasing research effort to utilize them for bio-scaffolding, drug delivery, and antibacterial treatment, ${ }^{17-20}$ all of which are rooted in the nano-bio interface. Nonetheless, to the best of our knowledge, no single publication has yet summarized this particular aspect, as done for other clay types. ${ }^{11}$

Herein, we aim to provide a thorough overview of both fundamental and applicative aspects of HNTs' nano-bio interface, as illustrated in Fig. 2. We start with a short background of HNTs physiochemical properties, followed by a discussion on the biocompatibility of HNTs and highlighting inconsistencies within this wide definition. Next, the latest findings and applications regarding the interface of HNTs with bacteria, algae and fungi, as well as mammalian cells are discussed in dedicated chapters.

\section{Noteworthy background literature}

Before surging into the main topic of this review, we would like to refer the readers to landmark reviews which lay the background and present potential biomedical applications. First is the comprehensive review by Joussein et al., ${ }^{13}$ which provides a thorough background on the geology of HNTs and discusses their intriguing chemo-physical properties. Also, several chapters in the book Nanosized Tubular Clay Minerals Halloysite and Imogolite ${ }^{21}$ give an excellent overview on HNTs mineralogy, ${ }^{22,23}$ methods for characterization, ${ }^{24,25}$ safety considerations, ${ }^{26}$ modification strategies, ${ }^{27,28}$ and 

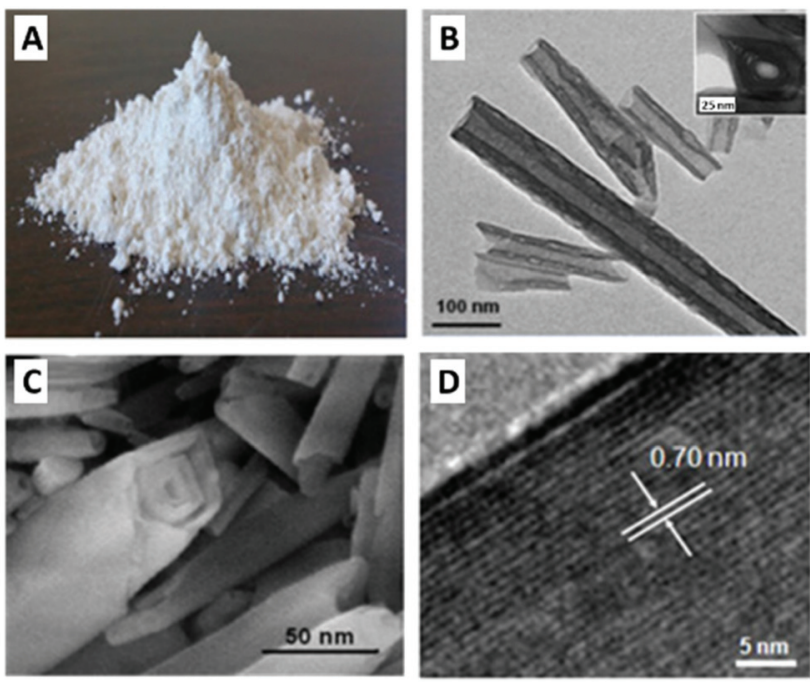

E

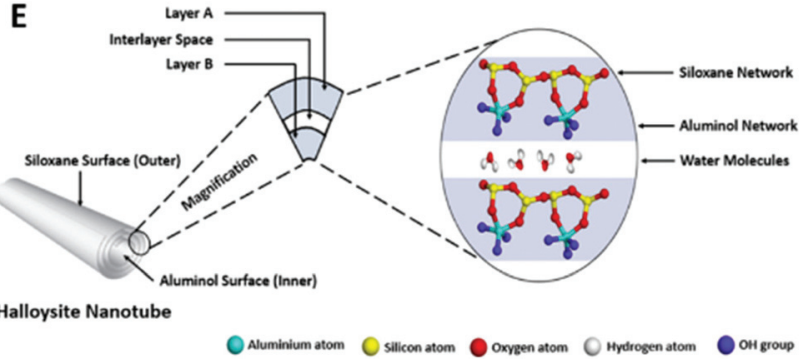

Fig. 1 Halloysite tubular morphology, nanostructure and chemistry: pristine halloysite as seen by the naked eye (A); TEM image of halloysite elongated nanotubes with characteristic length - the hollow lumen is clearly observed between the darker tube walls; inset showing tube cross-section (B); SEM image of halloysite nanotube edge depicting the rolled layers which form the tube walls $(C)$; high-resolution TEM image of the alumina and silica lattice of dehydrated halloysite. Thickness of one layer $\left(d_{001}=7 \AA\right)$ is indicated with white arrows (D); schematic illustration for halloysite chemistry of $1: 1$ aluminosilicate layers with intercalated water molecules (E). (A) and (E) reproduced from ref. 29. Copyright 2016, and ref. 42. Copyright 2018, respectively, with permission from Elsevier, (B-D) reproduced with permission from ref. 35. Copyright 2011, American Chemical Society.

applications. ${ }^{29-33}$ Additional more recent reviews which highlight the physical and chemical modification of HNTs for a range of future applications are. ${ }^{15,34,35}$ Other noteworthy reviews by leading research groups in the field focus on the prominent biomedical avenues ${ }^{16-19,35,36}$ in general, and drug delivery in particular. ${ }^{20,37-39}$

\section{HNTs - overview}

\subsection{HNTs origin and properties}

Omalius d'Halloy first described halloysite in 1826 as a clay mineral of the kaolin group with higher water content. Almost 200 years later, we start to grasp the implications the minute water presence on the nanostructure and potential biotechnological applications of these clays. ${ }^{14}$ Clay minerals are natural materials comprised of layered tetrahedral silica oxide and octahedral alumina oxide. As part of the kaolin group, the ratio between alumina and silica layers in halloysite is $1: 1$ and so it is identified as a 1:1 phyllosilicate. Halloysite also contains intercalated monolayer of water molecules between every two adjacent alumina-silica double layers; thus its general formula approximates to $\mathrm{Al}_{2} \mathrm{Si}_{2} \mathrm{O}_{5}(\mathrm{OH})_{4} \cdot n \mathrm{H}_{2} \mathrm{O}(n=4$ for fully hydrated form $).{ }^{23}$ Pure halloysite is found in several deposits around the globe (USA, New Zealand, China, Canada, and Turkey), and consumed in tons each year, mostly by the ceramics industry. ${ }^{40,41}$ The unique property of halloysite is its tubular morphology (Fig. 1B, C and E), suggested to be the result of platy kaolinite deformation accomplished by hydration. Tube characteristic length is 600-900 nm with outer diameter of about $50 \mathrm{~nm}$ and inner diameter of $15 \mathrm{~nm}$ (Fig. 1B and C). ${ }^{13,20,42}$ Due to its nanostructure, the material is frequently referred to as halloysite nanotubes (HNTs). HNTs are considered a mesoporous material with specific surface area of 50-60 $\mathrm{m}^{2} \mathrm{~g}^{-1}$, and bulk density of $2.53 \mathrm{~g} \mathrm{~cm}^{-3} \cdot{ }^{22}$ Being a natural mineral, HNTs size, shape and impurities profile may differ significantly according to their origin. Some HNTs are spherical whereas other are extremely elongated and may reach a length of a few microns. ${ }^{13}$ The tube consists of 10-15 rolls of double layer with a maximum interlayer gap of $10 \AA$ for fully hydrated HNTs and $7 \AA$ for dehydrated, see Fig. 1D and E. HNTs exhibit a dual chemistry of negatively-charged silica on the outer surface and positively-charged alumina on the inner lumen surface. The overall characteristic $\zeta$-potential (zetapotential) of HNTs is about $-30 \mathrm{mV}$ at $\mathrm{pH} 4-8$. Consequently, HNTs aqueous suspension is only stable for 2-3 hours before agglomeration occurs, ${ }^{43}$ unless surfactants are applied. HNTs possess some cation exchange capacity of $30-50 \times 10^{-2} \mathrm{~mol}$ $\mathrm{kg}^{-1}$. Calcination of HNTs at $460{ }^{\circ} \mathrm{C}$ will cause de-hydroxylation with a loss of about $12 \mathrm{wt} \%$ though the tubular morphology collapses only at $900{ }^{\circ} \mathrm{C}$ and above. ${ }^{28}$ In dispersions of high concentrations $(2-40 \mathrm{wt} \%),{ }^{44}$ HNTs behave like a liquid crystal with a nematic phase. ${ }^{45}$

\subsection{Toxicity and biocompatibility}

3.2.1 Pristine HNTs. Almost any publication, in which new applications of biological relevance for HNTs are presented, states that the HNTs are natural, abundant, low-cost, and biocompatible. While there is no doubt regarding the former three adjectives, HNTs biocompatibility is still under debate. ${ }^{14}$

Due to the morphological resemblance of HNTs to the wellstudied carbon nanotubes (CNTs), it is inevitable to compare the toxicity of these two nanotubes families.

Table 1 compares the main properties and elicited toxicity thresholds for HNTs and multiwalled CNTs (MWCNTs). We focus on MWCNTs (and not single-walled CNTs) due to the similarity in their characteristic dimensions, aspect ratio and specific surface area values to those of HNTs, as shown in Table 1. Yet, as the composition of these two families of nanomaterials is different, aluminosilicate $v s$. pure carbon, they exhibit intrinsically different surface chemistries and charge. The toxicity thresholds, presented in the table, are categorized by the organism type and are hierarchically organized, from murine models 


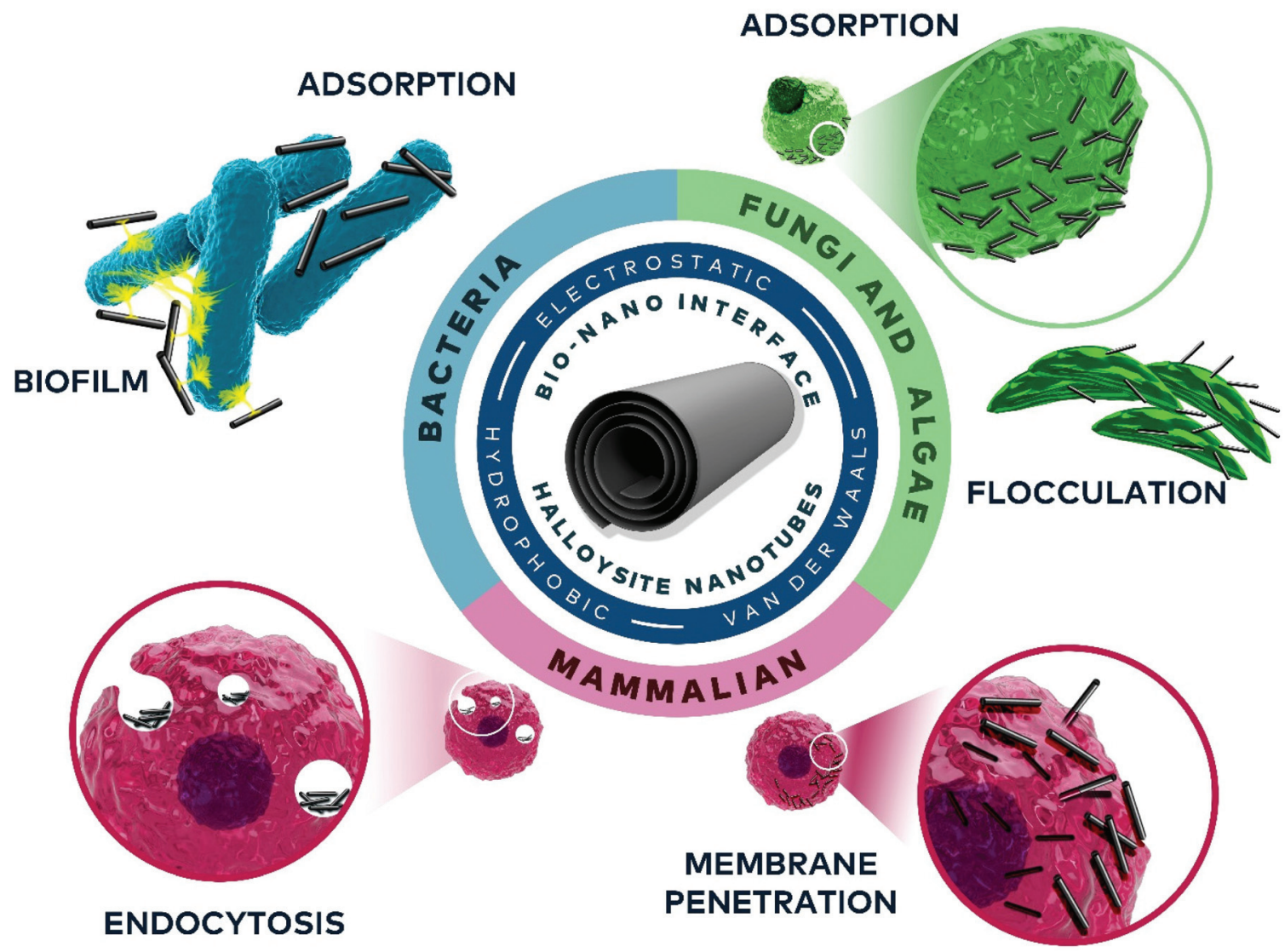

Fig. 2 A scheme of the nano-bio interface of HNTs and cells along with the relevant mechanisms and interactions. Natural aluminosilicate halloysite nanotubes possess a mesoporous diameter and submicronic to microns length. A direct contact between biological cells and particles is first established through physical attraction. Electrostatic charge differences between cell wall and HNTs (pristine or modified) or hydrophobic interactions between hydrophobized HNTs and cell membrane will eventually draw clay and cell to a vicinity at which Van der Waals forces apply. In some cases, HNTs may even serve as a chemoattractant and promote bacteria proliferation at their proximity. HNTs effect on the viability of the cells or their proliferation is still under debate, as accumulated findings range between high degree of biocompatibility to cell damage, induced by reactive oxygen species (ROS) generated by HNTs siloxane groups, high aluminum content originating from HNTs alumina or mechanical cell injury inflicted by the rigid nanotubes. Once in direct contact, cells interact with HNTs in a variety of aspects: algae cells co-aggregated with HNTs will tend to flocculate; whereas, bacteria could secrete a biopolymeric matrix and incorporate the clay nanotubes into their biofilm structure. Mammalian cells show a high degree of HNTs uptake through their membrane, whether via active endocytosis of HNTs aggregates or penetration of the high-aspect ratio nanotubes into the soft phospholipid bilayer of the cell. Inside the cell, the HNTs are transported by the actin and microtubules network towards the nucleus where the non-biodegradable clay particles are usually assigned for exocytosis.

and mammalian cells, through non-mammalian models to bacteria. While HNTs are perceived as "more safe" than CNTs $^{36}$ and numerous papers describe them as "safe", $, 17,36,46$ it is evident from the table, and current studies, that such a conclusion is premature. We believe that this conception originates from the limited available data on HNTs; whereas, CNTs toxicity has been studied for more than two decades. As such, data with clinical relevance, in vivo administration, ${ }^{47,48}$ long-term exposure, ${ }^{49-54}$ and importantly the underlying mechanisms ${ }^{55}$ are already available. As toxicity studies vary in their conditions and type, Table 1 provides only rough values for HNTs and MWCNTs. For the latter, the readers are encouraged to refer to the cited literature. In the next section, we provide an up-to-date detailed summary on HNTs toxicity and highlight the aforementioned complexity of the subject.
From a regulatory point of view, although kaolin clay minerals are affirmed as generally recognized as safe (GRAS) for indirect food contact by the United States Food and Drug Administration (FDA), halloysite as a nanomaterial is not yet approved for any sort of intake. ${ }^{78}$ Indeed, work is underway to regularize HNTs for future applications. ${ }^{79}$

Assessment of human exposure is limited to studies related to occupational inhalation scenarios, as HNTs are elongated nanoparticles and non-biodegradable they may pose a risk in a solid aerosol form. Koivisto et al. ${ }^{56}$ have recently studied HNTs related occupational inhalation hazard by analysing images of particles from air sampled adjacent to HNTs pouring area (100 g at a rate of $0.5 \mathrm{~kg} \mathrm{~min}^{-1}$ for ten times). Although only few particles possessed a dangerous aspect ratio of $>3$, as a precaution, the conclusion is to avoid exposure to HNTs dust. 
Table 1 A comparison between HNTs and MWCNTs: main characteristic properties, including dimensions, chemical composition, surface chemistry and charge, as well as toxicity threshold values. The latter are organized in a hierarchal manner, starting from murine models through mammalian cell cultures and common non-mammalian model organisms to bacteria

\begin{tabular}{|c|c|c|c|}
\hline & Feature & HNTs & MWCNTs \\
\hline \multirow[t]{12}{*}{ Properties } & Description & $\begin{array}{l}\text { A natural clay mineral comprises of } 1: 1 \text { aluminosilicate } \\
\text { double layer rolled into a tube with a maximum } \\
\text { interlayer gap of } 7-10 \AA \text { (ref. 13) }\end{array}$ & $\begin{array}{l}\text { A synthesized allotrope of carbon comprising of } \\
\text { graphene sheets rolled at various chiral } \\
\text { configurations into tubes which could be single or } \\
\text { multi-walled with interlayer gap of } 3.4 \AA \text { (ref. 53) }\end{array}$ \\
\hline & Dimensions & & \\
\hline & Length & $600-900 \mathrm{~nm}$ & $15000 \mathrm{~nm}$ \\
\hline & Diameter & Outer: $50 \mathrm{~nm}$ Inner: $15 \mathrm{~nm}$ (ref. 13, 20 and 42) & 5-100 nm (ref. 57) \\
\hline & Aspect ratio & $1-50^{22,56}$ & $15-3000^{57,58}$ \\
\hline & $\begin{array}{l}\text { Specific surface } \\
\text { area }\end{array}$ & $50-60 \mathrm{~m}^{2} \mathrm{~g}^{-1}$ (ref. 22$)$ & $100 \mathrm{~m}^{2} \mathrm{~g}^{-1}$ (ref. 58) \\
\hline & Chemistry & & \\
\hline & Composition & $\mathrm{Al}_{2} \mathrm{Si}_{2} \mathrm{O}_{5}(\mathrm{OH})_{4} \cdot n \mathrm{H}_{2} \mathrm{O}(n=4 \text { for fully hydrated form })^{13}$ & Pure carbon \\
\hline & $\begin{array}{l}\text { Surface } \\
\text { chemistry }\end{array}$ & $\begin{array}{l}\text { Siloxane groups with some exposed OH groups on tube } \\
\text { edges, external surface defects (silanol and aluminol), } \\
\text { and on lumen surface (aluminol) }\end{array}$ & Carbon atoms at $\mathrm{sp}^{2}$ hybridization ${ }^{57,58}$ \\
\hline & Physical & & \\
\hline & Zeta potential & $-30 \mathrm{mV}$ (ref. 43 ) & $-15--40 \mathrm{mV}$ (ref. 58 and 60) \\
\hline & Hydrophobicity & Hydrophilic; contact angle $<10^{\circ}$ (ref. 22$)$ & Hydrophobic $;{ }^{57}$ contact angle $>156^{\circ}$ (ref. 61$)$ \\
\hline
\end{tabular}

Toxicity In vivo (murine models)
Pulmonary
Intratracheal instillation - HNTs elicit lighter inflammatory response in comparison to MWCNTs at the same dose level of up to $125 \mu \mathrm{g}$ (ref. 62) $5 \mathrm{mg}$ per $\mathrm{kg}$ body weight per day for 30 days
(Total: $150 \mathrm{mg}$ per kg body weight) $\begin{array}{ll}\text { Intravenous } & 10 \mathrm{mg} \text { per } \mathrm{kg} \text { body weight per week ( } 3 \text { weeks) } \\ & \text { No significant effect on mouse body weight }\end{array}$
In vitro $^{a}$ 75-1000 $\mu \mathrm{g} \mathrm{mL}$ $200 \mathrm{mg}$ per $\mathrm{kg}$ body weight per day for 10 days
(Total: $2000 \mathrm{mg}$ per $\mathrm{kg}$ body weight)
$0.5 \mathrm{mg}$ per $\mathrm{kg}$ body weight per week (4 weeks)
No significant effect on mouse body weight ${ }^{60}$
40-20000 $\mu \mathrm{g} \mathrm{mL}^{-1} \mathrm{MWCNTs}^{51,52}$
Environmental
Zebrafish
Nematode
Protozoa
$25 \mathrm{mg} \mathrm{mL}^{-1}$ (ref. 67)
$>50 \mathrm{mg} \mathrm{mL}^{-1}$ (ref. 68 and 69)
$0.6-10 \mathrm{mg} \mathrm{mL}^{-1}$ (ref. 70)
$0.1-2.5 \mathrm{mg} \mathrm{mL}^{-1}$ (ref. 74-77)
(7.5-100 $\mu \mathrm{g} \mathrm{mL}^{-1}$ for SWCNTs $\left.{ }^{51}\right)$
Bacteria $^{b}$

$$
\begin{aligned}
& 100-200 \mathrm{mg} \mathrm{mL}^{-1} \text { (ref. } 71 \text { and 72) } \\
& 100 \mathrm{mg} \mathrm{mL}^{-1} \text { (ref. 73) } \\
& 1 \mathrm{mg} \mathrm{mL} \text { (ref. } 72)^{-1} \\
& 0.01-100 \mathrm{mg} \mathrm{mL}^{-1} \text { (ref. } 58 \text { and 77) }
\end{aligned}
$$

${ }^{a}$ HNTs: See Table 2 for more details regarding the studied cells types; MWCNTs: bronchial epithelial cells (BEAS2B), human T lymphocytes; SWCNTs: mesothelioma cell line MSTO-211H, human embryo kidney (HEK 293), human epithelial-like HeLa cells. ${ }^{b}$ HNTs: See Fig. 3 for details regarding the types of studied bacteria; MWCNTs: Salmonella typhimurium, E. coli, Bacillus subtilis.

In the vast majority of biological applications, HNTs are dispersed in aqueous media and are not used in their pure solid form.

Table 1 summarizes the toxicity threshold values reported for various HNTs administration routes in murine models. Oral administration of a high dosage of HNTs $(50 \mathrm{mg}$ per $\mathrm{kg}$ body weight daily for 30 days) was found to be toxic and the mice suffered from pulmonary fibrosis, possibly caused by the accumulation of aluminium in their lungs. ${ }^{63}$ Yet, no adverse effects were observed at a lower dosage of $5 \mathrm{mg}$ per $\mathrm{kg}$ body weight. These results are further confirmed in a recent study of the same group, showing normal mice weight gain at a lower oral dose of $5 \mathrm{mg} \mathrm{kg} \mathrm{kg}^{-1}$ body for 30 days; whereas, a higher dose ( $50 \mathrm{mg} \mathrm{kg}{ }^{-1}$ ) incited a reversible inflammation of the small intestine. ${ }^{64}$ Although the intravenous administration of non-biodegradable substances is usually ruled out, Wu et al. reported that the tail intravenous injection of short HNTs $(<200 \mathrm{~nm})$ to mice $(5 \mathrm{mg}$ per $\mathrm{kg}$ body weight twice a week for 3 weeks) had no significant effect on the mice body weight after 21 days. $^{65}$
The cytotoxicity of HNTs towards cancer and human cells was thoroughly studied, see Table 2, revealing intracellular accumulation and a concentration dependent effect. Yet, HNTs concentration in these studies was limited to $<1000 \mu \mathrm{g}$ $\mathrm{mL}^{-1}$, and at $1000 \mu \mathrm{g} \mathrm{mL} \mathrm{m}^{-1}$ a clear cytotoxic effect was observed. ${ }^{80}$ Moreover, we should highlight that as HNTs are a natural resource, their characteristics (namely, dimensions and impurities) are highly origin-dependent and thus, any toxicity study should be coupled with a thorough physiochemical characterization.

HNTs toxicity was also studied in few non-mammalian animal models, including Caenorhabditis elegans (C. elegans), ${ }^{68,69}$ Paramecium caudatum, ${ }^{70}$ and zebrafish (Danio Rerio). ${ }^{67}$ For the latter, high concentrations $\left(25 \mathrm{mg} \mathrm{mL}^{-1}\right)$ were not found to exert adverse effects on embryos and even promoted their hatchability. In adult zebrafish, the ingested HNTs accumulated in the gastrointestinal tract and were then gradually excreted. A similar work investigated the effect of HNTs on the nematode $C$. elegans, concentrations of up to $1 \mathrm{mg} \mathrm{mL} \mathrm{m}^{-1}$ were found safe and microscopy studies revealed 
Table 2 Cytotoxicity of HNTs towards cancer and human cells

\begin{tabular}{|c|c|c|c|}
\hline Cell type & $\begin{array}{l}\text { Time } \\
\text { frame }\end{array}$ & Toxicity threshold & Ref. \\
\hline A549 (human lung epithelial cancer cell line) & $24 \mathrm{~h}$ & No toxic effect up to $100 \mu \mathrm{g} \mathrm{mL}^{-1}$ & 81 \\
\hline $\begin{array}{l}\text { HUVECs (umbilical vein endothelial cells) and MCF-7 } \\
\text { (human breast adenocarcinoma) }\end{array}$ & $72 \mathrm{~h}$ & No significant apoptosis up to $200 \mu \mathrm{g} \mathrm{mL}^{-1}$ & 67 \\
\hline HeLa (human cervical carcinoma) and MCF-7 cell line & $24-72 \mathrm{~h}$ & No toxic effect up to $75 \mu \mathrm{g} \mathrm{mL} \mathrm{m}^{-1}$ & 82 \\
\hline Caco-2/HT29-MTX (intestinal cell co-culture cells) & $6 \mathrm{~h}$ & $\begin{array}{l}\text { No cytotoxic effect up to } 100 \mu \mathrm{g} \mathrm{mL}^{-1} \\
\text { Proteomics suggests processes of cell growth and cell injury }\end{array}$ & 83 \\
\hline $\begin{array}{l}\text { HepG2 (hepatocellular carcinoma), HCT116 (colorectal carcinoma } \\
\text { cells) }\end{array}$ & $24-72 \mathrm{~h}$ & $\begin{array}{l}\text { Cytostatic at } 500 \mu \mathrm{g} \mathrm{mL} \mathrm{m}^{-1} \\
\text { Cytotoxic at } 1000 \mu \mathrm{g} \mathrm{mL}\end{array}$ & 84 \\
\hline Human peripheral blood lymphocytes & $24-72 \mathrm{~h}$ & $\begin{array}{l}\text { Cytogenetic toxicity at only } 1000 \mu \mathrm{g} \mathrm{mL}^{-1} \text { by blocking the } \\
\text { passage of cell cycle }\end{array}$ & 84 \\
\hline
\end{tabular}

that the HNTs passed through the gastrointestinal track of C. elegans without harming its viability or fertility. ${ }^{68,69}$ Paramecium caudatum, freshwater protozoa, was incubated with varying HNTs concentrations $\left(0.6-10 \mathrm{mg} \mathrm{mL}^{-1}\right.$ for 1 and $24 \mathrm{~h}$ ) and no toxicity was observed. It was shown that the cells ingested the nanotubes through their oral grove into intracellular food vacuoles. ${ }^{70}$

In microorganisms, HNTs were mainly studied in the context of biocidal activity. Theoretically, HNTs do not meet the common clay properties to exhibit bactericidal effects; ${ }^{85,86}$ namely, the ability to sustain metal ions in solution $\left(\mathrm{Fe}^{2+}, \mathrm{Al}^{3+}\right)$ and sufficient interlayer cation exchange capacities. Literature in the field reveals a wide variety of possible effects of HNTs on bacteria, as summarized in Fig. 3 , and reported effects range from bacteriostatic to proliferative (and may be even contradicting). The latter was shown by Panchal et al. who have used
HNTs to stabilize crude oil emulsions in sea water and demonstrated the compatibility of $5-10 \mathrm{mg} \mathrm{mL} \mathrm{m}^{-1}$ HNTs with the oildegrading bacteria Alcanivorax borkumensis (A. borkumensis). ${ }^{87}$ Conversely, Abhinayaa et al. ${ }^{74}$ determined the minimum inhibitory concentration (MIC) of pristine HNTs for phytopathogenic bacteria (e.g., Agrobacterium tumifaciens and Xanthomonas oryzae) to be $\sim 2.5 \mathrm{mg} \mathrm{mL}^{-1}$ in a viability assay employing Resazurin dye. Lower concentrations of HNTs $\left(>0.6 \mathrm{mg} \mathrm{mL} \mathrm{m}^{-1}\right)$ inhibited to some extent bacteria growth rate and damaged cell membrane integrity, and this behaviour was ascribed to the effect of siloxane groups (on HNTs surface) in combination with the generation of reactive oxygen species (ROS). Choi et al. have found that HNTs are in fact slightly toxic towards Escherichia coli $(E$. coli $)$ BL21(DE3) at a concentration range of 0.01 to $1.0 \mathrm{mg} \mathrm{mL}{ }^{-1} .^{75}$ After $8 \mathrm{~h}$ of incubation in the presence of $1.0 \mathrm{mg} \mathrm{mL} \mathrm{m}^{-1}$, E. coli viability decreased to $85 \%$. Metabolic

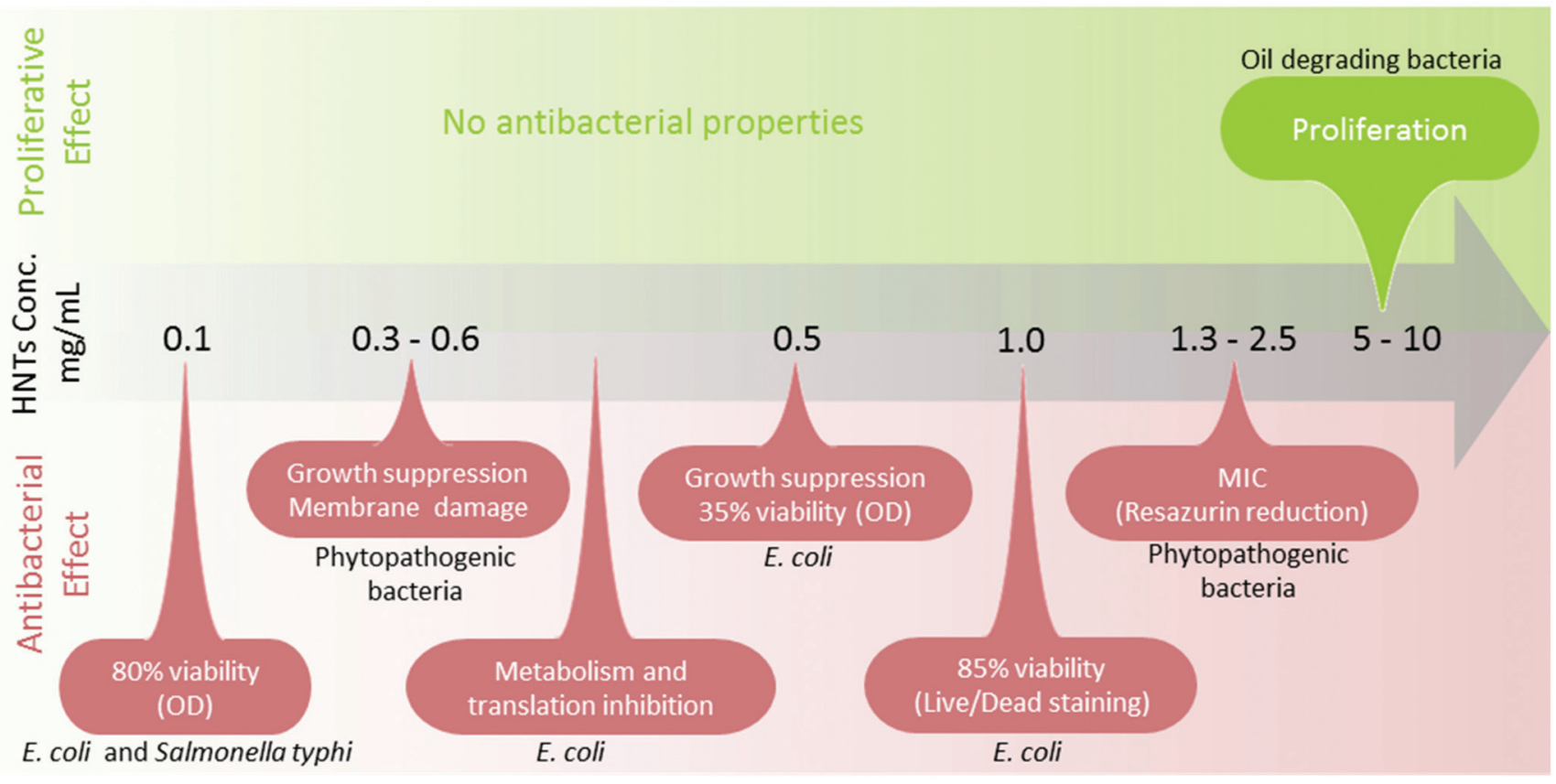

Fig. 3 HNTs bio-adverse or proliferative effect on bacteria. The investigation of HNTs biocompatibility towards bacteria is still ongoing as results suggest a mixed (and even contradicting) effect ranging from proliferative to bacteriostatic, depending on HNTs concentration, bacteria type, and assay type (indicated in parentheses). 
activity, plasmid replication and protein expression were even more drastically hindered at lower HNTs concentrations and the authors also ascribed this behaviour to ROS generation. On the other hand, when tested for antibacterial activity in a Petri dish, pristine HNTs did not demonstrate any inhibitory capabilities for E. coli or Staphylococcus aureus (S. aureus). ${ }^{76}$ Taylor et al. have studied HNTs toxic and mutagenic effect on $E$. coli and Salmonella typhimurium as a function of air and light exposure. The results showed that HNTs were not mutagenic to the bacteria but were slightly toxic as a result of light-dependent oxidative stress. ${ }^{77}$ Thus, HNTs compatibility with bacterial cells is still under debate as a singular toxicity study has to be performed for each defined situation in terms of bacteria type, environmental conditions and assay type. We should highlight that as HNTs are not soluble and exhibit pronounced intrinsic optical density (OD), assay type and conditions should be carefully chosen and adjusted.

While interactions of bacteria and HNTs are widely studied, we found only two papers by Konnova et al. ${ }^{88,89}$ addressing the interactions of yeast (Saccharomyces cerevisiae) and HNTs. The yeast cells were found to maintain their viability and fertility at HNTs concentration of up to $2.5 \mathrm{mg} \mathrm{mL}^{-1}$.

To summarize, the origin of HNTs toxicity stems from the combination of their nanoscale diameter, high aspect ratio, and chemical composition. Yet, the role of each of these properties is contextual and depends on the target organism, tissue and cell type. Examples for such include bacterial membrane damage induced by siloxane generated $\mathrm{ROS} ;{ }^{75,77}$ oxidative stress exhibited by $C$. elegans ${ }^{69}$ toxic levels of aluminium accumulated in organs of mouse fed with HNTs; ${ }^{63}$ mammalian cell injury ${ }^{83}$ inflicted by the high aspect ratio HNTs penetrating the cell phospholipid bilayer; ${ }^{48,112}$ and pulmonary inflammation induced by the inhalation of HNTs aerosols ascribed to the fiber paradigm. ${ }^{56}$

3.2.2 Modified HNTs. As pristine HNTs have limited biological applicability, in many cases, HNTs are either modified or used as a component in hybrids and nanocomposites. Thus, any physical or chemical modification of the natural clay is likely to change its excreted toxicity. To that end, residual reagents participating in the modification process or loaded payloads may leak over time into the environment. Yet, owing to HNTs tubular shape, the leakage rate of any toxic compound should be relatively slow, minimizing the environmental risk in comparison to other clay materials. ${ }^{6}$

In this section, we will discuss the effect of different modifications on HNTs toxicity. We only focus on the main modification routes; namely, acidic etching, surfactant and polymer adsorption, silanization, as well as decoration with nanoparticles.

Acidic etching of HNTs is beneficial for increasing their specific surface area and porosity, but it is found to alleviate pulmonary inflammation in mice compared with pristine HNTs. In vitro cytotoxicity, however, is not affected by the etching procedure. ${ }^{62}$

Surfactant adsorption is one of the most common ways to enhance HNTs dispersion stability in aqueous medium and increase their active surface area. In terms of toxicity, HNTs modified with adsorbed stearyldimethylbenzylammonium chloride, were included in the diet of rats $^{90}$ and piglets ${ }^{91}$ for potential protection against the mycotoxin zearalenone through its adsorption inside the animal gastrointestinal track. In both cases, the modified-HNTs feed did not impair the animal vitality as well as its fertility. HNTs surface coating with poly(ethylene glycol) (PEG) and proteins was shown to improve their biocompatibility. PEG-grafted HNTs were shown to be uptaken by HeLa (human cervical carcinoma) and HepG2 (hepatocellular carcinoma) cells ${ }^{92}$ and were less cytotoxic than pristine HNTs (with thresholds of $500 \mu \mathrm{g} \mathrm{mL} \mathrm{m}^{-1}$ and $100 \mu \mathrm{g} \mathrm{mL} \mathrm{m}^{-1}$, respectively). Bovine serum albumin (BSA) coating of HNTs also increased HNTs biocompatibility towards E. coli (up to $0.05 \mathrm{mg} \mathrm{mL}{ }^{-1}$ for $8 \mathrm{~h}$ of incubation). ${ }^{75}$ A different strategy to enhance HNTs biocompatibility is by their incorporation within polymer matrices. ${ }^{93}$ For example, HNTs/chitosan nanocomposites were shown to exhibit a similar extent of biocompatibility as neat chitosan towards fibroblasts (NIH3T3, mouse). ${ }^{94}$

Another prevalent approach for hydrophobization or activation of HNTs surface is through its organosilanization. HNTs hydrophobized with octadecyltrimethoxylsilane (ODTMS) promoted the proliferation of the hydrocarbonoclastic bacteria $A$. borkumensis. ${ }^{87}$ Regarding mammalian cells, Rozhina et al. showed the uptake of ODTMS-modified HNTs (up to $250 \mu \mathrm{g} \mathrm{mL}^{-1}$ ) by human lung carcinoma alveolar epithelial A549 cells without inducing membrane damage or affecting cell viability. ${ }^{95}$ Sánchez-Fernández et al. have studied the cytotoxicity of HNTs treated with two hydrophobic organosilanes: trimethoxy(propyl)silane, and triethoxy(octyl)silane towards C6 glioma cells. ${ }^{96}$ The results showed that at concentration in which pristine HNTs were biocompatible $(500 \mu \mathrm{g}$ $\mathrm{mL}^{-1}$ ), the silanized clays exhibited higher cytotoxicity, inducing cell death by apoptosis after $24 \mathrm{~h}$. A rather different conclusion was drawn by the work of Vergaro et al. ${ }^{82}$ where the cytotoxicity of 3-aminopropyltriethoxysilane (APTES)-modified HNTs towards cancer cell lines (MCF-7 and HeLa) was found to be similar to that of pristine HNTs for up to $75 \mu \mathrm{g} \mathrm{mL} \mathrm{m}^{-1}$. This discrepancy could be attributed to chemical differences between the tested organosilanes or to the cytotoxicity assay (apoptotic assessment vs. cell metabolism measurement). Similarly, Choi et al. showed that APTES-modified HNTs (0.01-1.0 $\mathrm{mg} \mathrm{mL}^{-1}$ ) were cytotoxic towards $E$. coli at least to the same extent as pristine HNTs. ${ }^{75}$

Abhinayaa et al. assessed the effect of HNTs decoration with iron oxide nanoparticles (used mainly to magnetize the nanotubes) on its cytotoxicity and compared it with that of free iron oxide nanoparticles and pristine HNTs. ${ }^{97}$ The researchers showed that the $\mathrm{HNTs} / \mathrm{Fe}_{3} \mathrm{O}_{4}$ hybrids, at concentrations of 0.5-2.5 mg mL $\mathrm{mg}^{-1}$, suppressed the inherent toxicity of the $\mathrm{Fe}_{3} \mathrm{O}_{4}$ nanoparticles towards $E$. coli and Bacillus subtilis (B. subtilis) for a duration of 2-6 hours. Moreover, both $\mathrm{Fe}_{3} \mathrm{O}_{4}$ nanoparticles and $\mathrm{HNTs} / \mathrm{Fe}_{3} \mathrm{O}_{4}$ hybrids were found to be biocompatible with Vero monkey kidney epithelia cells, but the latter were cytotoxic for human lung epithelial cancer cell line (A549). 
In conclusion, HNTs toxicity is profoundly dependent on their chemical modification and thus their toxicological and environmental impact should be thoroughly addressed under relevant conditions. Therefore, caution is advised when relying on the general statement that HNTs are "safe" or "biocompatible".

\section{Bacteria-HNTs interactions}

\subsection{Principles of bacteria-clay interactions}

Soil bacteria have been evolving alongside clay minerals for millions of years while developing mechanisms to exploit clays for their benefit. However, the environmental impact of modified clays on these indigenous populations is still unravelling. In addition, still, little is known about the interactions between non-soil bacteria and clays. ${ }^{6,12}$

There are many biochemical possibilities for a bacterial cell to interact with the clay surface, and these may vary depending on clay type, bacteria type, medium properties, and flow conditions. $^{12}$

Bacterial cell wall - whether Gram-positive or negative - has a negative charge; thus, electrostatic attraction between bacteria and positively-charged clays (natural or modified) under the appropriate $\mathrm{pH}$ conditions and ionic strength is expected. ${ }^{12}$ Hydrophobic surfaces, characterizing non-oxidized clays, may promote the adhesion of hydrophobic cells, regardless of electrostatic repulsion, as was shown for hydrophobized montmorillonite and E. coli. ${ }^{98}$ Under flow, exists a delicate balance between mixing currents conferring suspension stability and excessive shear forces that may detach bacteria and clay or even put bacteria into stress, alternating their morphology and metabolism. ${ }^{99}$

From an environmental point of view, soil bacteria, have evolved to alter clay minerals altogether through reduction of trace elements incorporated in these materials (mostly Fe(III)), changing layer charge or cation exchange capacity (CEC), and even dissolving part of the crystal lattice. ${ }^{7}$ Co-aggregation of bacteria and clay may also occur through biofilm formation and flocculation. Clay platelets (such as kaolinite and montmorillonite) may adhere to cell wall, and the strong polysaccharide biofilm matrix secreted by the bacteria could penetrate the surrounding clay pores altering clay physical properties. ${ }^{7}$ Pseudomonas syringae incubated with smectite in a minimal aqueous medium (containing the minimal amount of nutrients required for bacteria growth) has shown to incorporate clay particles into biofilm within $3 \mathrm{~h}$, as suggested by microscopy and X-ray studies. ${ }^{100,101}$ Huang et al. ${ }^{102}$ further studied the forces between clay and bacteria within a biofilm using atomic force microscopy (AFM), which minimizes sample preparation artefacts. They revealed that bacteria adhesion to kaolinite was more profound onto the edge surfaces rather than the basal surfaces of clay, probably due to electrostatic attraction. In addition, the same study showed that bacteria formed more biofilm on minerals within minimal media than within enriched media.
Some works suggest that these bacteria-clay interactions are beneficial for the bacteria as was evidenced by their survival through dust storms traveling long distances upon clay particles that also protected them from dehydration and UV damage. ${ }^{100}$ Nonetheless, more recent research emphasizes the antimicrobial effect of clays exerted via a variety of mechanisms, including positive surface charge, decoration with antibacterial metal oxides (e.g., zinc, silver and iron oxides), or a payload of antibacterial compounds. ${ }^{12}$ Yet, pristine clays that exhibit antibacterial properties mostly contain reduced metals $\left(\mathrm{Fe}^{2+}, \mathrm{Al}^{3+}\right)$ and are capable to expend to allow cation adsorption; ${ }^{85,86}$ whereas, HNTs do not meet these criteria.

\subsection{Adsorption}

The research regarding the extent and mechanisms of bacteria adhesion to pristine HNTs is rather scarce; ${ }^{12}$ yet, modified HNTs were harnessed to interact with bacteria for two main biotechnological purposes: oil spill bioremediation and exerting antimicrobial activity - all are elaborated in the next paragraphs.

One of the earliest works on bacteria adhesion to HNTs was conducted by Barr, already in 1957, in an attempt to utilize HNTs as an ingredient of intestinal adsorbent preparation to treat intestinal infections. ${ }^{103}$ The study was simple, letting aqueous suspensions of bacteria (at various concentrations $\left.10^{6}-10^{9} \mathrm{CFU} \mathrm{mL}^{-1}\right)$ and clay $\left(2 \mathrm{mg} \mathrm{mL}^{-1}\right)$ to mix at $\mathrm{pH} 6.8 \pm$ 0.1 for $30 \mathrm{~min}$ and stand for $3 \mathrm{~h}$, while the clay settled to the bottom of the tube. Bacterial load reduction was defined as the difference between plate counts for the supernatant and a control sample that did not contain any clay. The study included four known gastrointestinal pathogens: S. aureus, Proteus vulgaris, Salmonella enteritidis, and Shigella dysenteriae. Halloysite proved to be rather inferior in adsorbing the bacteria with maximal reduction of bacterial load of only $12 \%$ for S. aureus; whereas, other clay types exhibited up to $95 \%$ reduction. The author postulated that the bacteria did not actually adhere to the clay but were rather swept down by the settling particles. In another work, negatively-charged E. coli were coated with HNTs by the layer-by-layer technique, employing layers of polycationic poly(allylamine hydrochloride) (PAH), HNTs, PAH, and a final layer of anionic sodium poly (styrenesulfonate) (PSS). ${ }^{68}$

\subsection{Proliferation}

Meanwhile, another more promising approach for utilizing bacteria-HNTs interactions emerged when Panchal et al. ${ }^{87}$ showed that HNTs attract and stimulate the viability of the hydrocarbonoclastic bacteria $A$. borkumensis. In combination with the HNTs ability to form stable oil in water Pickering emulsion, it was demonstrated that $0.5-1 \mathrm{wt} \%$ of HNTs successfully emulsified $1: 30 \mathrm{oil} / \mathrm{sea}$ water mixtures and enhanced the proliferation of oil-degrading bacteria on the droplet surface, as shown in Fig. 4A and B. Moreover, hydrophobized HNTs (achieved via silanization) showed even better emulsification capabilities without the need of toxic surfactants. These findings were later developed into active films of polyvinyl alcohol/alginate in 

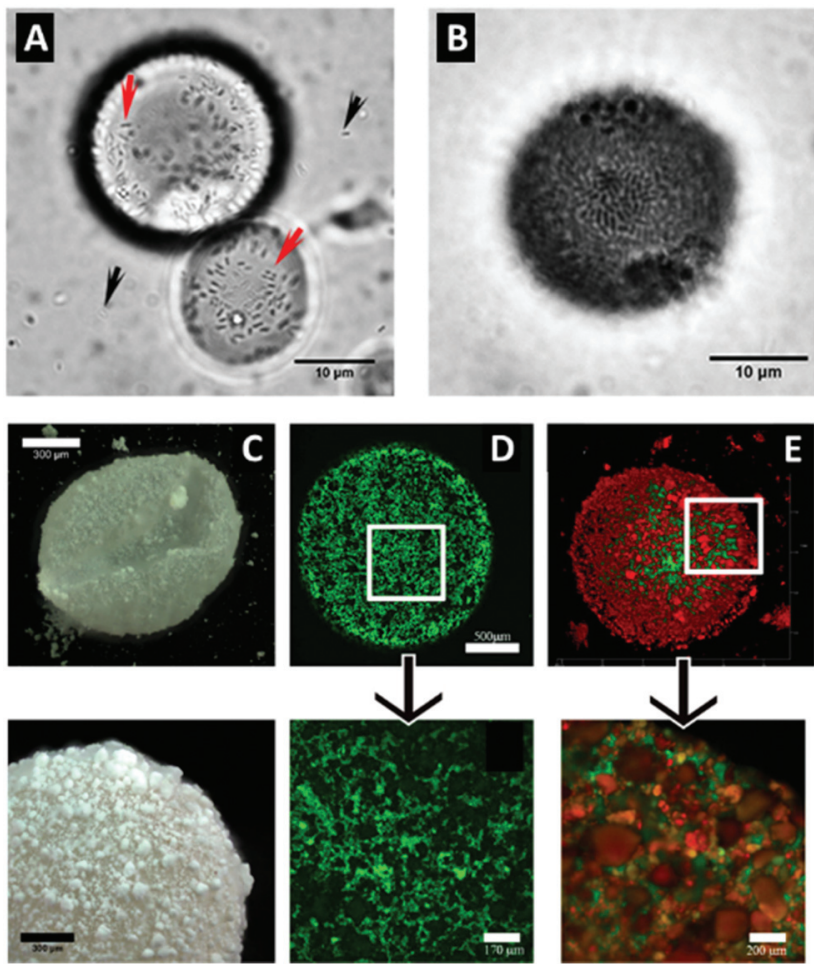

Fig. 4 Hydrophobized HNTs enhance the stability of Pickering emulsions and promote bacteria proliferation. (A and B) Micrographs of droplets of crude oil emulsion stabilized by ODTMS-modified HNTs inoculated with the oil-degrading bacteria A. borkumensis after 1 and 3 days, respectively. Black arrows indicate freely dispersed bacteria cells and red arrows mark proliferating cells attached to HNTs on droplet surface. (CE) Micrographs of aqueous bacteria culture droplets in air stabilized by ODTMS-modified HNTs, as imaged by: dark-field microscopy (C) and confocal microscopy (D-E) of green stained $A$. borkumensis culture (D); and green stained $E$. coli culture with red-stained HNTs (E). (A and B) reproduced from ref. 87. Copyright 2018, with permission from Elsevier. (C-E) reproduced with permission from ref. 106. Copyright 2019, American Chemical Society.

which HNTs and oil-degrading bacteria were incorporated. ${ }^{104}$ Another strategy to improve the oil emulsifying capability of HNTs and bacteria proliferation involved the functionalization of clay with an amphiphilic polypeptide. ${ }^{105}$

The same Pickering emulsion stabilization principle was also harnessed by Panchal et al. to stabilize droplets of aqueous bacterial cultures in air by a layer of hydrophobized HNTs, as depicted in Fig. 4C-E. ${ }^{106}$ Moreover, these liquid 'marbles' were further strengthened via biofilm formation on inner droplet wall and promoted bacteria survival for up to 4 days at ambient air.

\subsection{Antibacterial activity}

The most studied application of HNTs with regard to bacteria is by no doubt the antibacterial activity of modified HNTs. ${ }^{107}$ Antimicrobial compounds are either adsorbed or grafted onto the HNTs outer surface - or alternatively - loaded into the tube lumen by mere sonication and vacuuming. The loaded HNTs are advantageous as they stabilize the antibacterial com- pound and enable its sustained release. HNTs for antibacterial applications can be categorized as: (i) free modified HNTs in a particulate system, (ii) component of a polymeric nanocomposite.

Numerous antibacterial compounds were loaded into the HNTs, such as antibiotics, ${ }^{108-113}$ disinfectants, ${ }^{114,115}$ essential oils, ${ }^{116-119}$ and antimicrobial peptides. ${ }^{120}$ For example, loading of the disinfectant chlorhexidine gluconate resulted in a sustained release rate, three times slower than the free compound. ${ }^{114}$ Such preparations can be administered as pastes and ointments, or even directly sprayed onto surfaces as an aqueous suspension (3-5 wt\% HNTs). ${ }^{107}$ In another work, lower concentrations of salicylic acid were required to exert antibacterial effect against Pseudomonas fluorescens in the presence of HNTs than for the neat salicylic acid, possibly due to some synergism between the acid and HNTs. ${ }^{121}$ A unique selective antibacterial activity was demonstrated by Fakhrullina et al. ${ }^{122}$ who fed C. elegans nematodes with dextrin end-capped HNTs loaded with curcumin. They showed that the loaded HNTs can eradicate Serratia marcescens ( $S$. marcescens), a nematode pathogen, within the nematode gut while maintaining the viability of E. coli. This selective activity was also demonstrated in biofilms, where the curcumin-loaded HNTs exhibited a more disruptive effect on $S$. marcescens biofilms, see Fig. 5 .

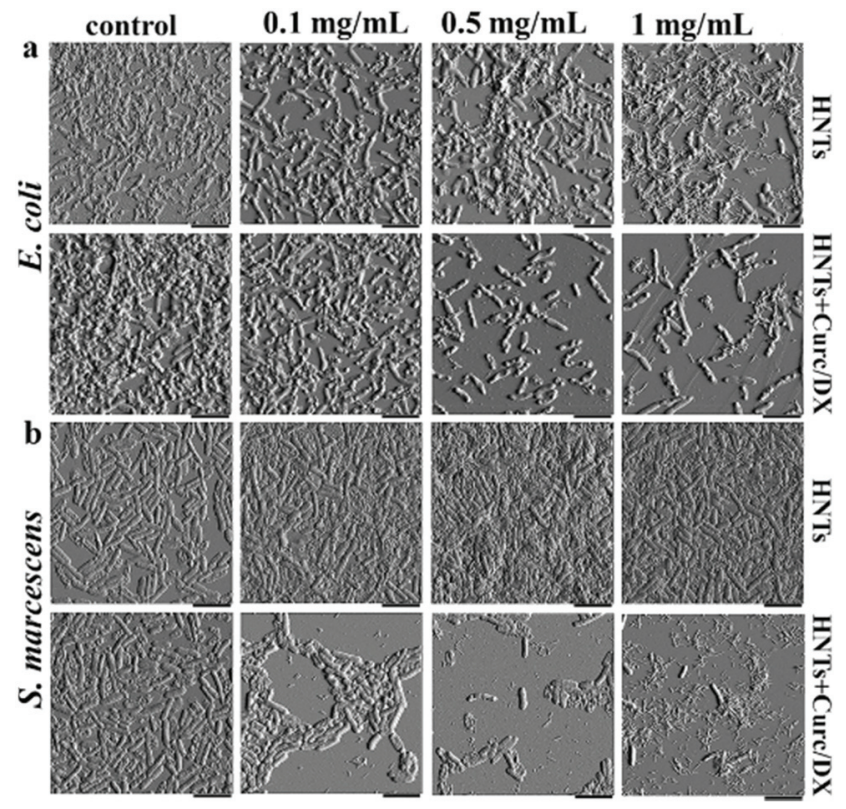

Fig. 5 Selective antibiofilm activity of curcumin-loaded HNTs. Atomic force micrographs of (a) E. coli and (b) S. marcescens which were incubated for $72 \mathrm{~h}$ with different concentrations of HNTs (pristine or loaded). Selective antibiofilm effect of the curcumin load is demonstrated as S. marcescens biofilm is more profoundly interrupted by the loaded HNTs at all studied concentrations when compared to E. coli biofilms. Pristine HNTs exert minor antibiofilm effect on $E$. coli, but promote biofilm formation by S. marcescens. HNTs + Curc/DX refers to curcumin loaded HNTs end-capped with dextrin, scale bar $=4 \mu \mathrm{m}$. Reproduced with permission from ref. 122. Copyright 2019, American Chemical Society. 
Abhinayaa et $a l .{ }^{74}$ have investigated the efficacy of surfactant-modified HNTs $\left(0.3\right.$ and $\left.0.6 \mathrm{mg} \mathrm{mL}{ }^{-1}\right)$ in protection against phytopathogenic bacteria (Agrobacterium tumifaciens, Xanthomonas oryzae, and Ralstonia solanacearum) by measuring the respective MIC values, growth rate, cell membrane integrity, ROS production, and biofilm formation. Their main finding was that cetyltrimethylammonium bromide (CTAB)modified HNTs were the most potent in killing the bacteria, due to their positive zeta potential, small size and narrow size distribution, as well as their hydrophobicity. CTAB-modified HNTs were also studied against the Gram-positive bacteria Bacillus subtilis, exerting stronger antibacterial and antibiofilm activity than pristine HNTs and sodium dodecyl sulphatemodified HNTs. ${ }^{123}$ HNTs decorated with metal oxide nanoparticles, such as zinc oxide, silver oxide or photocatalytic titanium oxide have been shown to exert antibacterial activity, as the HNTs surface provides numerous sites for the particles anchoring and formation. ${ }^{107}$

Loaded HNTs can be incorporated into various polymeric matrices, providing a mean to protect the active compound during polymer processing and allowing for a sustained release of the active cargo. ${ }^{93,107}$ The loaded HNTs are introduced either during the polymerization process, ${ }^{113}$ or dispersed within a polymer melt ${ }^{116-119}$ or solution. ${ }^{108,124}$ The resulting polymer/ HNTs nanocomposites can be used in many formats, including active films,${ }^{116-119}$ electrospun substrates, ${ }^{125,126}$ membranes, ${ }^{124}$ dental coatings, ${ }^{127-129}$ and bone cement. ${ }^{113,130}$

In some cases, the addition of HNTs into the matrix not only slows down the release rate of the antimicrobial compound, but also improves the physical properties of the resulting nanocomposites. For example, HNTs enhanced the tensile strength of antibacterial nanocomposites composed of antibiotics-loaded HNTs incorporated into a gelatin elastomer. ${ }^{131}$ The utilization of such antibacterial nanocomposites is not limited to biomedical or environmental applications; active food packaging could extend food shelf life by releasing volatile antimicrobial agents into the package headspace. ${ }^{119}$ Our group has developed antimicrobial nanocomposites in which HNTs loaded with essential oils are dispersed in polymer matrices, as illustrated in Fig. 6A and B, such as low-density polyethylene ${ }^{117,132}$ or polyamides. ${ }^{118}$ The HNTs enhance the thermal stability of the volatile essential oils under the harsh processing conditions of the polymer (up to $250{ }^{\circ} \mathrm{C}$ and high shear mixing), and allow for a sustained release of the oils into the package headspace, while the plastic films quality was not compromised.

\section{Algae/fungi-HNTs interactions}

\subsection{Adsorption}

Owing to micro-eukaryotes nature, their interactions with HNTs may differ from that of bacteria and HNTs.

Back in the $20^{\text {th }}$ century, HNTs were found to be an inferior flocculant for fungi spores, compared to other clay types. This behaviour was ascribed to electrical repulsion between the nega-

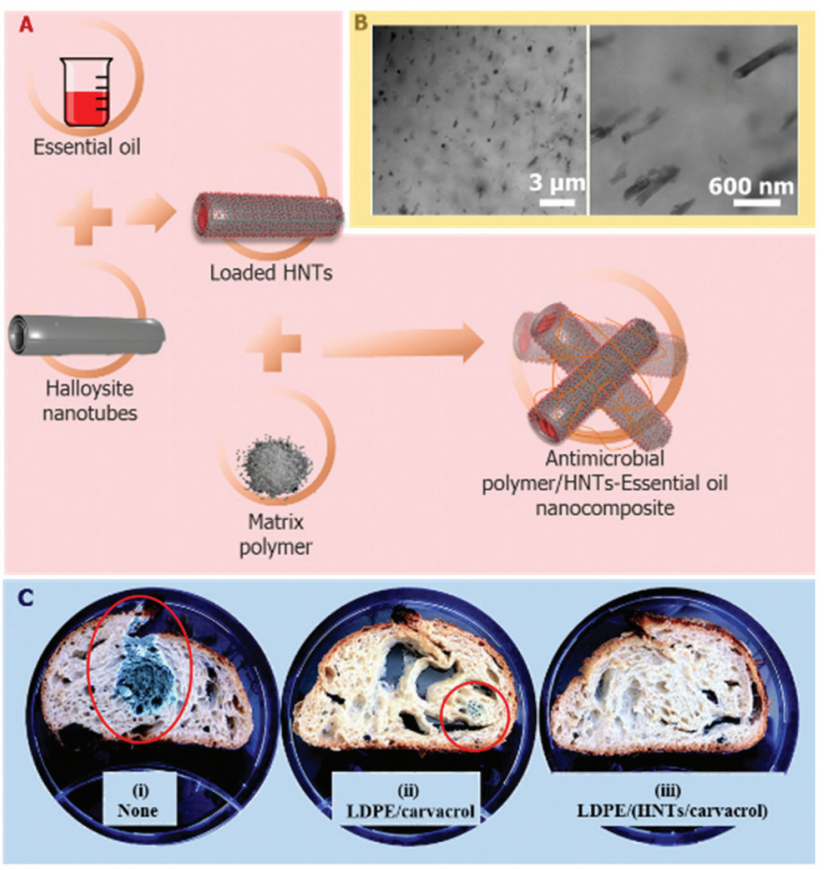

Fig. 6 Antimicrobial polymer/HNTs nanocomposites which are comprised of essential oil-loaded HNTs. (A) Schematic illustration of the preparation route of the nanocomposites. The HNTs are first loaded with essential oils (such as carvacrol) and then melt compounded with low density polyethylene (LDPE) and processed into films by extrusion. (B) High-resolution scanning transmission electron microscopy images of the resulting nanocomposite film (crossed-sectioned under cryogenic conditions), depicting the fine dispersion of the loaded HNTs within the polymeric matrix. Reproduced from ref. 117. (C) Images of preservativefree bread slices after inoculation with Penicillium and 11 days of storage (i) with no package, (ii) packed in LDPE/carvacrol film (no HNTs), (iii) packed in LDPE/carvacrol-loaded HNTs film. Red circles mark fungal growth. Reproduced from ref. 119.

tively-charged HNTs and the fungal spores. ${ }^{133}$ Nonetheless, Ahn et $a .^{134}$ recently succeeded in doping the fungal mycelium of Aspergillus fumigatus and Ganoderma lucidum with pristine HNTs by simply dipping the mycelia in a HNTs suspension. The authors related the strong affinity between the HNTs and the fungal mycelia to electrostatic forces or dipole-dipole interactions between HNTs siloxane surface and the fungal mycelium, in addition to the mechanical incorporation of the nanotubes inside the mycelia network. This system was studied for environmental bioremediation applications.

Konnova et al. have shown that the formation of the socalled "cyborg" yeast cells is possible by the mere mixture of the cells together with HNTs decorated with magnetic $\mathrm{Fe}_{3} \mathrm{O}_{4}$ nanoparticles in water. ${ }^{88}$ Electrostatic forces were suggested as a possible source for the attraction between the positivelycharged magnetite-decorated HNTs and negatively-charged yeast cells. The cells have been shown to retain their viability in the presence of the decorated HNTs and were also magnetized to allow their facile collection via magnetic field. As a future application for their discovery, the authors suggested exploiting the tubular morphology of HNTs and use the clay 
coating as a carrier for bioactive payloads such as enzymes, nutrients or antibiotics that may assist the "cyborg" cells to survive extreme conditions. The same group also demonstrated the assembly of a shell of HNTs around yeast cells, using a layer-by-layer technique, while retaining their viability for one generation. ${ }^{89}$

For aquaculture, Tan et al. ${ }^{135}$ have demonstrated the advantage of APTES-modified HNTs as an effective flocculent for the microalgae Scenedesmus dimorphus, optimizing their harvest within 2 min at pH 3.0 and HNTs to biomass ratio of $1: 1$, as shown in Fig. 7. The modified HNTs did not hinder lipid extraction from the harvested microalgae and did not contaminate their extracts. The rapid flocculation was suggested to be the result of electrostatic attraction between the positively-charged amine modified HNTs and the negatively-charged microalgae.

\subsection{Antifungal activity}

Similar to bacteria, HNTs were also employed for controlled release of antifungal compounds such as clotrimazole ${ }^{136}$ for treatment of candidiasis or quaternary ammonium compounds $^{137}$ and iodopropynyl butylcarbamate (IPBC) against mould and stain fungi growth, ${ }^{138}$ as well as various essential oils and their components for inhibiting food-spoilage fungi. ${ }^{116,118,119}$ For clotrimazole, its loading into $\beta$-cyclodextrin-modified HNTs has resulted in an almost zero order release profile for over 5 hours which allowed to overcome the drug poor bioavailability. ${ }^{136}$ In the case of IPBC $^{138}$ and essential oils, ${ }^{116,118,119}$ their loading in pristine or modified HNTs was shown to significantly prolong the release of the active compound and retain its efficient antifungal activity even in complex food matrices, as depicted in Fig. 6C.

\section{Mammalian cells-HNTs interactions}

\subsection{Principles of cell-HNTs interactions}

Some of the most noteworthy biomedical applications of HNTs are based on their interaction with cells through which cells
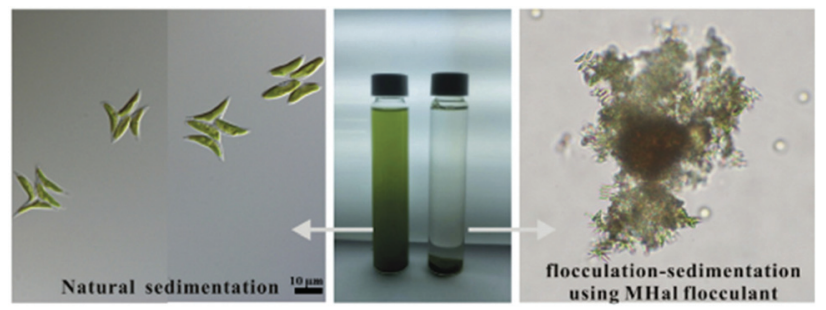

Fig. 7 Amine-modified HNTs induce rapid flocculation and sedimentation of the microalgae Scenedesmus dimorphus. Light microscope images of the freshwater microalgae with APTES-modified HNTs (termed as MHal, right panel) and without HNTs (left panel). Positively charged APTES-HNTs co-aggregate with negatively charged microalgae cells causing subsequent flocculation and sedimentation significantly shortening the harvest process. Reproduced from ref. 135. Copyright 2019, with permission from Elsevier. can subsequently uptake the clay nanotubes or adhere to them. $^{30}$

Generally, the interaction between cells and any type of nanoparticles is affected by various forces such as van der Waals and electrostatic forces. ${ }^{139}$ Thus, particle, size, shape and surface charge play a crucial role; particles that are smaller, more elongated or more positively-charged can penetrate more easily through the negatively-charged cell membrane. ${ }^{1,139-141}$ Nanoparticles in the range of 50-1000 nm present several routes of cell entry: passive diffusion through cell membrane, active non-receptor mediated phagocytosis or receptor-mediated endocytosis. Elongated carbon nanotubes (CNTs), for example, have been shown to be uptaken via all three routes. ${ }^{142}$ The same principles are relevant for clay nanoparticles in which the positively-charged lattice edges can adhere to the cell negatively-charged membrane. ${ }^{143}$ Then, high aspect-ratio clay nanoparticles, may penetrate the phospholipid bilayer to accumulate in the membrane, ${ }^{48,112}$ or access the cell interior. $^{143}$

As discussed in section 3.2, HNTs (modified or unmodified) uptake by cells is common and mostly does not impede their viability ${ }^{67}$ but may inhibit lysosomal activity. ${ }^{95}$ The uptake of HNTs by HeLa and MCF-7 cells was demonstrated as a twostep process, in which HNTs concentrate at cell perimeter, and then accumulate in the cell. ${ }^{26,82}$ In human lung cancer cells (A549), the internalization mechanism was described as a receptor-mediated endocytosis (both caveolae- and clathrindependent), as schematically illustrated in Fig. 8A. ${ }^{144}$ Subsequently, HNTs were found to be intracellularly transported through actin filaments and microtubules accumulating at the proximity of the nucleus ${ }^{82,145}$ and finally sent to the Golgi apparatus or into a lysosome. Fig. $8 \mathrm{~B}$ and $\mathrm{C}$ depicts the accumulation of HNTs within the cells as observed by different microscopy techniques.

Human colon cancer cells (HT-29) that were exposed to HNTs demonstrated dynamic kinetics of HNTs transfer which consisted of the following stages: (i) HNTs accumulation in the cell membrane through endocytosis (ii) HNTs depletion due to escape from the lysosome and exocytosis, and (iii) steady intracellular HNTs content balanced by endocytosis and exocytosis. ${ }^{146}$

The extent of HNTs internalization was size dependent, as short HNTs (250 nm long) were found to show a higher accumulation rate in the HT-29 cells in comparison to longer HNTs. ${ }^{146}$ This was explained by the fact that shorter HNTs exhibit more exposed tube edges that are positively charged leading to enhanced attraction to the negatively-charged cell membrane and higher endocytosis internalization rates. Hydrophobic ODTMS-modified HNTs also exhibited superior accumulation at the vicinity of A549 cell nuclei in comparison to pristine HNTs without impairing cell viability. ${ }^{95}$ Positively-charged polycation-modified HNTs were shown to aggregate more onto the cell membrane of A549 cells than pristine HNTs; nonetheless, these modified HNTs exerted a cytotoxic affect and altered cell nuclei morphology. ${ }^{147}$ 

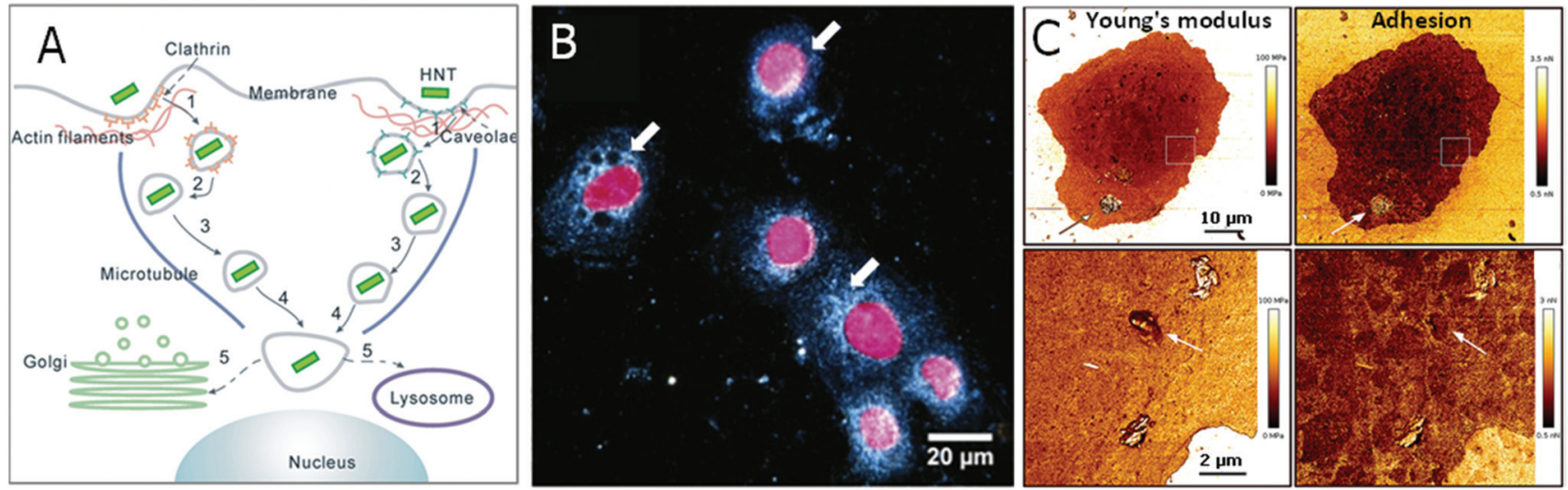

Fig. 8 HNTs uptake by mammalian cells. (A) A schematic illustration for HNTs routes of uptake and intracellular transport. After adsorption to cell surface, HNTs are first internalized through endocytosis. Then the membrane-encapsulated HNTS are transported slowly via actin filaments and subsequently more rapidly on the microtubules towards the nucleus vicinity. There, the HNTs are assigned to a lysosome or to the Golgi apparatus. (B) Dark field microscopy image of a human lung cancer cell (A549) with intracellularly accumulated HNTs. Cell nuclei are stained red with 4',6-diamidino-2-phenylindole dihydrochloride (DAPI). White arrows mark the internalized HNTs. (C) AFM image of an A549 cell with ODTMS-modified HNTs aggregated on cell membrane (indicated by arrows on upper panel) and internalized ODTMS-modified HNTs (indicated by arrows on lower panel). Young's modulus of HNTs, whether adsorbed on cell exterior or internalized, is higher than that of the cell, whereas only internalized HNTs exhibit adhesion rates that are identical to that of surrounding cell membrane. (A) reproduced by permission from Springer, ref. 144. Copyright 2018; (B) and (C) reproduced from ref. 147. Copyright 2019, and ref. 95. Copyright 2020, respectively, with permission from Elsevier.

\subsection{Cell capture}

One of the well-studied application of cells-HNTs interactions is the adhesion of circulating tumour cells (CTC) onto HNTs coated surfaces. Hughes et al. have pioneered this field by demonstrating the advantage of coating the inner surface of polyurethane-based tubing with HNTs, which were modified with the cell adhesion molecule P-selectin. ${ }^{148}$ The coating was shown to enhance the capture of circulating leukemic cells by altering the flow behavior of the cells and specifically slowing down their velocity on the roughened surface. Immobilization of specific antibodies (for targeting cancer cells) on to the HNTs ${ }^{149,150}$ has further improved the specific capturing of this system for up to $50 \%$ of the CTC in patient blood samples. Nonspecific adhesion of leukocyte was minimized by treating the HNTs with sodium dodecanoate, which increased the negative charge of the HNTs. ${ }^{151}$ An alternative strategy to form CTC-capturing coatings onto glass substrates employed evaporative self-assembly of sodium poly(styrenesulfonate) treated HNTs from concentrated aqueous suspensions. ${ }^{152}$ Subsequent APTES treatment of the highly-ordered HNTs assembly was used to stabilize the coating and enhance the attraction of CTC. Immobilization of biotinylated specific antibody onto these HNTs-based coatings, as schematically illustrated in Fig. 9, has resulted in an improved capture yield of MCF-7 (human breast adenocarcinoma) cells to $92 \%$ within 3 hours of incubation. ${ }^{153,154}$

\subsection{Bioscaffolds and tissue engineering}

Such oriented self-assembled coatings of HNTs on glass ${ }^{155,156}$ or polylactic acid (PLA) ${ }^{157}$ were also shown to passively affect the orientation of mesenchymal stem cells and to promote their differentiation. Cell contact guidance is enhanced by the

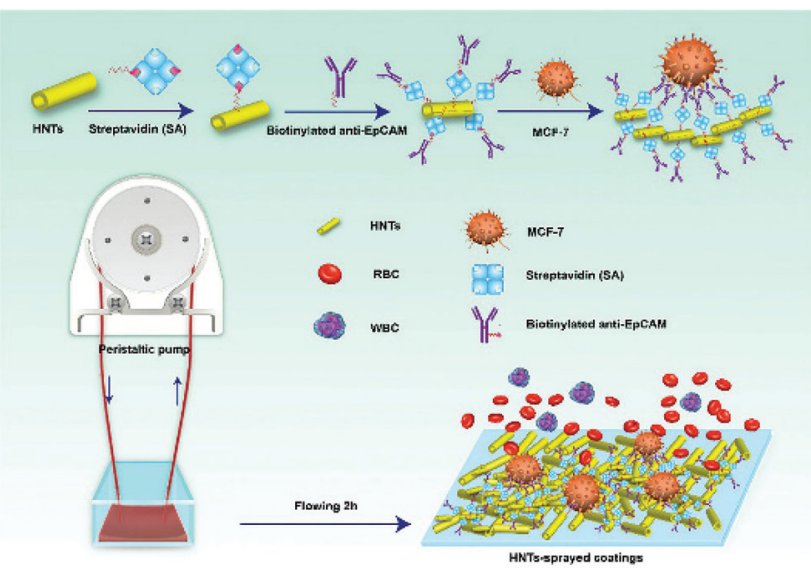

Fig. 9 Illustration of a multifunctional coating of HNTs on the inner surface of microtubes for specific capture of circulating tumor cells (MCF-7, human breast adenocarcinoma) in real blood samples. The HNTs increase the active surface for cell capture and serve as an anchorage for specific anti-EpCAM antibody via biotin-streptavidin interactions. $\mathrm{RBC}=$ red blood cells, $\mathrm{WBC}=$ white blood cells. Reproduced from ref. 154. Copyright 2018, with permission from Elsevier.

self-assembled HNTs substrate which mimics both micro- and nanoscopic features of the biological tissue at the critical dimensions. The former is crucial for cell spatial organization through F-actin alignment; whereas, the latter provides the roughness needed to induce cell differentiation. ${ }^{158}$

As for 3D scaffolds, HNTs are stiff and tough, making them ideal for hard-tissue engineering or as fillers for other biopolymers. ${ }^{16}$ Poly(methyl methacrylate) (PMMA) bone cement was prepared with HNTs loaded with bone growth-promoting drugs and antibiotics which maintained high tensile strength 
and even promoted polymerization of bone cement through integration between acrylate and alumina in the HNTs. HNTs siloxane surface chemistry and elongated morphology enhanced the adhesion force between bone and bone cement. ${ }^{159,160}$ Huang et al. have incorporated HNTs into gelatin methacrylate hydrogel to evaluate its potential in promoting bone regeneration. In vitro, human dental pulp stem cells (hDPSCs) incubated with the hydrogel showed enhanced expression of osteogenesis related genes, and subsequently, better bone regeneration rates were observed in vivo for calvarial defects of rats. ${ }^{130}$ The same principles were implemented for HNTs-based dentist resins. HNTs, which acted both as the resin bulk and as a nanocarrier for antibiotics also sustained the release of barium sulphate (radiopaque agent). ${ }^{161-163}$ In other examples the incorporation of HNTs into bioscaffolds made of chitosan, agarose and gelatin enhanced scaffold strength, and adhesion to cells. In vivo studies in rats showed neoangiogenesis at the scaffold proximity without any inflammatory reactions. ${ }^{164,165}$ HNTs were also used to supplement scaffolds based on alginate, ${ }^{166}$ gellan gum ${ }^{167}$ and polycaprolactone, ${ }^{168}$ where silicate ions from HNTs were postulated to stimulate osteoblasts into collagen secretion.

\subsection{Targeted delivery}

Apart from surface coating, HNTs could be tailored to target cancer cells in suspension. Li et al. ${ }^{44}$ conjugated folic acid onto $\beta$-cyclodextrin coated magnetized HNTs and used this system to isolate and enrich SKOV3 (ovarian carcinoma cells), HeLa and A549 cancer cells in buffer and whole blood. These modified magnetic HNTs were found to selectively accumulate in the membrane of cells expressing the alpha folate receptor $(\alpha-\mathrm{FR})$ protein and allowed their magnetic capture, while retaining the cells viability.

The internalization of HNTs by cells was extensively utilized to develop various delivery systems for drugs (as reviewed by Lazzara et al. $^{169}$ ) and genes. ${ }^{170-173}$ Targeted delivery systems using HNTs, mostly for targeting cancer cells, have been extensively demonstrated in vitro. ${ }^{17,46,144,145,174-176}$ Few in vivo studies have attempted to target cancer cells via systemic administration. ${ }^{65,177-180}$ These advanced multifunctional HNTs enhance the efficacy of loaded anticancer drugs at lower doses and with lower systemic exposure. Hu et al. ${ }^{177}$ loaded doxorubicin in mercaptosilane-modified HNTs and endcapped the nanotubes with a redox responsive $\beta$-cyclodextrin functionalized with PEG-folate through adamantine$\beta$-cyclodextrin interactions, as illustrated in Fig. 10A. The folate residue functions as a targeting moiety via recognition by receptor-mediated endocytosis, and the $\mathrm{S}-\mathrm{S}$ linkage of the $\beta$-cyclodextrin end-cap, which is sensitive to the reducing intracellular environment, serves for triggered release. These multifunctional HNTs have demonstrated a 2-fold decrease in tumour size in comparison to the free doxorubicin. A folate recognition moiety was also used to functionalize short HNTs $\left(<200 \mathrm{~nm}\right.$ in length $\left.{ }^{181}\right)$ for targeted delivery of doxorubicin. ${ }^{65}$ These HNTs were shown to be internalized by penetrating the cell membrane, see Fig. 10B, as well as by endocytosis of larger
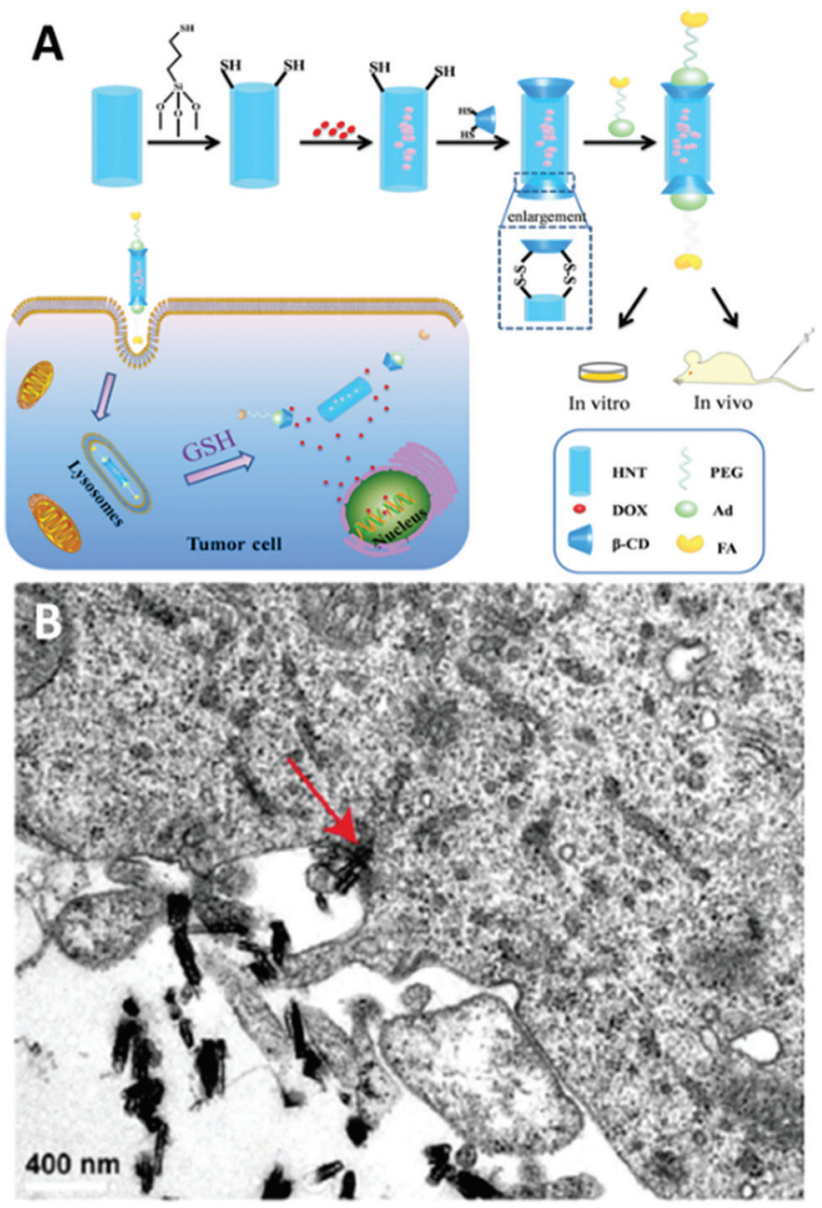

Fig. 10 Intracellular delivery of doxorubicin by systemic administration of folate-functionalized HNTs. (A) the synthetic route for functionalization of doxorubicin (DOX)-loaded HNTs with folic acid (FA) using a redox sensitive $\beta$-cyclodextrin $(\beta-C D)$ end-cap. HNTs are first silanized with (3-mercaptopropyl)trimethoxysilane and then loaded with DOX. Subsequently, loaded HNTs are end-capped with a thiolated $\beta$-cyclodextrin to which an adamantine (Ad)-PEG-folate (FA) moiety is attached via adamantine- $\beta$-cyclodextrin host-guest interactions. Following tail injection, folate recognition by receptors on tumour cells induce the internalization of the functionalized HNTs. Within the cell, drug release is triggered via glutathione (GSH) mediated cleavage of $\mathrm{S}-\mathrm{S}$ bond between thiolated HNTs and thiolated end-caps. (B) TEM image depicting the uptake of short functionalized HNTs by human breast adenocarcinoma cells (MCF-7). Red arrow indicates direct membrane penetration by a single HNT. Reproduced with permission from (A) reproduced with permission from ref. 177. (c) IOP Publishing. Reproduced with permission. All rights reserved; (B) Reproduced with permission from ref. 65. Copyright 2018, American Chemical Society.

particle aggregates. Upon injection, the modified HNTs were shown to exert a stronger anticancer activity than the free drug with lower levels of cytotoxicity. Furthermore, current works endeavour to equip the HNTs carriers with an advanced triggering mechanism to control drug release by external stimuli. ${ }^{179,180}$

A genetic therapy against bladder cancer using HNTs was also demonstrated by Liu et al. In this work, an effective loading was achieved based on electrostatic attraction between 
negatively-charged small interfering RNA (siRNA) and positively charged HNTs lumen. The injected complexes of loaded HNTs accumulated in the tumor silencing the receptor-interacting protein kinase 4 (RIPK4) gene and subsequently inhibiting tumour proliferation. ${ }^{173}$

\section{Conclusions and future perspective}

Halloysite nanotubes have gained a profound interest as an emerging multifunctional material for both environmental and biomedical applications. Their unique tubular nanostructure makes them especially appealing as multifunctional platforms for cells of all types. Each of the properties of HNTs' could be harnessed at the nano-bio interface for a desired task: HNTs toughness plays an important role in strengthening bio-scaffolds and bacterial biofilms, while its intrinsic porosity enables the diffusive mass transfer that is vital for cell survival. Their nano-scale hollow lumen is ideal for encapsulating bioactive cargos and their controlled release near or inside a target cell; while, the nanotube high aspect ratio promotes cell membrane penetration. Additionally, HNTs considerable surface area of dual alumina-silica chemistry enables various selective modifications, including functionalization with targeting probes for safer and more efficient drug delivery or hydrophobization for enhanced oil spill bioremediation.

The increasing popularity of HNTs is also attributed to their abundancy and low cost. As most clay minerals, pristine HNTs are relatively inexpensive in comparison to synthetic nanotubes (such as CNTs). Yet as the applicability of pristine HNTs is limited for biological applications, HNTs are often chemically modified which may significantly increase the cost. Furthermore, HNTs are generally considered as "safe" or "nontoxic"; but, this conclusion is premature. Caution should be made as their toxicological assessment is still in its infancy and should be further established. Moreover, as HNTs are natural nanomaterials, their properties vary and are origindependent, leading to possibly different toxicology profiles.

While, the interface of HNTs with viruses has not been well explored yet, we believe that the COVID-19 pandemic will accelerate research in this frontier. HNTs' nano-virus interface can provide novel solutions utilizing the superior adsorption capacity of HNTs. Several studies have reported the removal of viruses by adsorption from dilute aqueous solutions by different clays (montmorillonite, ${ }^{182}$ layered double hydroxides $^{11}$ and kaolinite ${ }^{182}$ - an approved pharmaceutical excipient clay mineral of the same kaolin group as halloysite). Moreover, a batch adsorption study from 1987 reported the superior performance of halloysite over kaolinite and montmorillonite for virus removal from water of poliovirus 2 , reovirus 3 , echovirus 7 , coxsackievirusB 5 , and echovirus $1 .^{183}$

Thus, the intriguing nano-bio interface of HNTs enables to design tailored solutions for numerous environmental, biotechnological, and medical challenges, and may present a safer, sustainable, and more affordable alternative for other synthetic nanomaterials. Yet, future research has to fully elucidate the long-term impact of HNTs (pristine and modified) on human health and ecology.

\section{Conflicts of interest}

There are no conflicts to declare.

\section{Acknowledgements}

This work was partially funded by the European Union's Horizon 2020 research and innovation programme grant number 720815. O. P. S is grateful to the Azrieli Foundation for the award of an Azrieli Fellowship.

\section{References}

1 A. E. Nel, L. Madler, D. Velegol, T. Xia, E. M. Hoek, P. Somasundaran, F. Klaessig, V. Castranova and M. Thompson, Nat. Mater., 2009, 8, 543-557.

2 R. F. Fakhrullin, A. I. Zamaleeva, R. T. Minullina, S. A. Konnova and V. N. Paunov, Chem. Soc. Rev., 2012, 41, 4189-4206.

3 V. Maheshwari, D. E. Fomenko, G. Singh and R. F. Saraf, Langmuir, 2010, 26, 371-377.

4 N. C. Bigall, M. Reitzig, W. Naumann, P. Simon, K. H. van Pee and A. Eychmuller, Angew. Chem., Int. Ed., 2008, 47, 7876-7879.

5 M. R. Dzamukova, A. I. Zamaleeva, D. G. Ishmuchametova, Y. N. Osin, A. P. Kiyasov, D. K. Nurgaliev, O. N. Ilinskaya and R. F. Fakhrullin, Langmuir, 2011, 27, 14386-14393.

6 B. Biswas, L. N. Warr, E. F. Hilder, N. Goswami, M. M. Rahman, J. G. Churchman, K. Vasilev, G. Pan and R. Naidu, Chem. Soc. Rev., 2019, 48, 3740-3770.

7 B. Mueller, Pedosphere, 2015, 25, 799-810.

8 L. Peña-Parás, J. A. Sánchez-Fernández and R. Vidaltamayo, Nanoclays for Biomedical Applications, in Handbook of Ecomaterials, 2018, ch. 50-1, pp. 1-19. DOI: 10.1007/978-3-319-48281.

9 J. D. D. Moraes, S. R. A. Bertolino, S. L. Cuffini, D. F. Ducart, P. E. Bretzke and G. R. Leonardi, Int. J. Pharm., 2017, 534, 213-219.

10 M. Massaro, C. G. Colletti, G. Lazzara and S. Riela, J. Funct. Biomater., 2018, 9, 58.

11 C. Forano, F. Bruna, C. Mousty and V. Prevot, Chem. Rec., 2018, 18, 1150-1166.

12 E. I. Unuabonah, C. G. Ugwuja, M. O. Omorogie, A. Adewuyi and N. A. Oladoja, Appl. Clay Sci., 2018, 151, 211-223.

13 E. Joussein, S. Petit, J. Churchman, B. Theng, D. Righi and B. Delvaux, Clay Miner., 2005, 40, 383-426.

14 G. J. Churchman, P. Pasbakhsh and S. Hillier, Clay Miner., 2018, 51, 303-308. 
15 Y. Zhang, A. Tang, H. Yang and J. Ouyang, Appl. Clay Sci., 2016, 119, 8-17.

16 M. Liu, R. Fakhrullin, A. Novikov, A. Panchal and Y. Lvov, Macromol. Biosci., 2019, 19, e1800419.

17 S. Satish, M. Tharmavaram and D. Rawtani, Nanobiomedicine, 2019, 6, 1-16.

18 X. Zhao, C. Zhou and M. Liu, J. Mater. Chem. B, 2020, 8, 838-851.

19 A. C. Santos, C. Ferreira, F. Veiga, A. J. Ribeiro, A. Panchal, Y. Lvov and A. Agarwal, Adv. Colloid Interface Sci., 2018, 257, 58-70.

20 Y. Lvov, W. Wang, L. Zhang and R. Fakhrullin, Adv. Mater., 2016, 28, 1227-1250.

21 P. Yuan, A. Thill and F. Bergaya, Nanosized Tubular Clay Minerals - Halloysite and Imogolite, Developments in Clay Science, Elsevier, Amsterdam, 2016, vol. 7.

22 H. Yang, Y. Zhang and J. Ouyang, Physicochemical Properties of Halloysite, in Nanosized Tubular Clay Minerals - Halloysite and Imogolite, ed. A. T. Peng Yuan and B. Faïza, Developments in Clay Science, Elsevier, 2016, ch. 4, vol. 7, pp. 67-91.

23 E. Joussein, Geology and Mineralogy of Nanosized Tubular Halloysite, in Nanosized Tubular Clay Minerals Halloysite and Imogolite, ed. A. T. Peng Yuan and B. Faïza, Developments in Clay Science, Elsevier, 2016, ch. 2, vol. 7, pp. $12-48$.

24 J. T. Kloprogge, Characterisation of Halloysite by Spectroscopy, in Nanosized Tubular Clay Minerals Halloysite and Imogolite, ed. A. T. Peng Yuan and B. Faïza, Developments in Clay Science, Elsevier, 2016, ch. 6, vol. 7, pp. 115-136.

25 T. Kogure, Characterisation of Halloysite by Electron Microscopy, in Nanosized Tubular Clay Minerals Halloysite and Imogolite, ed. A. T. Peng Yuan and B. Faïza, Developments in Clay Science, Elsevier, 2016, ch. 5, vol. 7, pp. 92-114.

26 M. C. Jaurand, An Overview on the Safety of Tubular Clay Minerals, in Nanosized Tubular Clay Minerals - Halloysite and Imogolite, ed. A. T. Peng Yuan and B. Faïza, Developments in Clay Science, Elsevier, 2016, ch. 20, vol. 7, pp. 485-508.

27 D. Tan, P. Yuan, D. Liu and P. Du, Surface Modifications of Halloysite, in Nanosized Tubular Clay Minerals Halloysite and Imogolite, ed. A. T. Peng Yuan and B. Faïza, Developments in Clay Science, Elsevier, 2016, ch. 8, vol. 7, pp. 167-201.

28 P. Yuan, Thermal-Treatment-Induced Deformations and Modifications of Halloysite, in Nanosized Tubular Clay Minerals - Halloysite and Imogolite, ed A. T. Peng Yuan and B. Faïza, Developments in Clay Science, Elsevier, 2016, ch. 7, vol. 7, pp. 137-166.

29 E. Abdullayev and Y. Lvov, Halloysite for Controllable Loading and Release, in Nanosized Tubular Clay Minerals Halloysite and Imogolite, ed. A. T. Peng Yuan and B. Faïza, Developments in Clay Science, Elsevier, 2016, ch. 22, vol. 7, pp. 554-605.
30 C. Aguzzi, G. Sandri, P. Cerezo, E. Carazo and C. Viseras, Health and Medical Applications of Tubular Clay Minerals, in Nanosized Tubular Clay Minerals - Halloysite and Imogolite, ed. A. T. Peng Yuan and B. Faïza, Development in Clay Science, Elsevier, 2016, ch. 26, vol. 7, pp. 708-725.

31 J. Huang, Z. H. Tang, X. H. Zhang and B. C. Guo, Halloysite Polymer Nanocomposites, in Nanosized Tubular Clay Minerals - Halloysite and Imogolite, ed. A. T. Peng Yuan and B. Faïza, Developments in Clay Science, Elsevier, 2016, ch. 21, vol. 7, pp. 509-553.

32 J. Matusik, Halloysite for Adsorption and Pollution Remediation, in Nanosized Tubular Clay Minerals Halloysite and Imogolite, ed. A. T. Peng Yuan and B. Faïza, Developments in Clay Science, Elsevier, 2016, ch. 23, vol. 7, pp. 606-627.

33 O. Poncelet and J. Skrzypski, Industrial Implications in the Uses of Tubular Clay Minerals, in Nanosized Tubular Clay Minerals - Halloysite and Imogolite, ed. A. T. Peng Yuan and B. Faïza, Development in Clay Science, Elsevier, 2016, ch. 27, vol. 7, pp. 726-734.

34 M. Massaro, G. Lazzara, S. Milioto, R. Noto and S. Riela, J. Mater. Chem. B, 2017, 5, 2867-2882.

35 M. Tharmavaram, G. Pandey and D. Rawtani, Adv. Colloid Interface Sci., 2018, 261, 82-101.

36 A. C. Santos, I. Pereira, S. Reis, F. Veiga, M. Saleh and Y. Lvov, Expert Opin. Drug Delivery, 2019, 16, 11691182.

37 Y. Lvov, A. Aerov and R. Fakhrullin, Adv. Colloid Interface Sci., 2014, 207, 189-198.

38 Y. M. Lvov and R. R. Price, Halloysite Nanotubules, a Novel Substrate for the Controlled Delivery of Bioactive Molecules, in Bio-inorganic Hybrid Nanomaterials: Strategies, Syntheses, Characterization and Applications, Wiley-VCH Verlag GmbH \& Co. KGaA., 2008, ch. 14, pp. 419-441. DOI: 10.1002/9783527621446.

39 M. Massaro, G. Cavallaro, C. G. Colletti, G. Lazzara, S. Milioto, R. Noto and S. Riela, J. Mater. Chem. B, 2018, 6, 3415-3433.

40 Y. M. Lvov, D. G. Shchukin, H. Mohwald and R. R. Price, ACS Nano, 2008, 2, 814-820.

41 Y. Lvov and E. Abdullayev, Prog. Polym. Sci., 2013, 38, 1690-1719.

42 E. Abdullayev, K. Sakakibara, K. Okamoto, W. Wei, K. Ariga and Y. Lvov, ACS Appl. Mater. Interfaces, 2011, 3, 4040-4046.

43 Y. Joo, J. H. Sim, Y. Jeon, S. U. Lee and D. Sohn, Chem. Commun., 2013, 49, 4519-4521.

44 X. Li, J. Chen, H. Liu, Z. Deng, J. Li, T. Ren, L. Huang, W. Chen, Y. Yang and S. Zhong, Colloids Surf., B, 2019, 181, 379-388.

45 Y. Lvov, A. Panchal, Y. Fu, R. Fakhrullin, M. Kryuchkova, S. Batasheva, A. Stavitskaya, A. Glotov and V. Vinokurov, Langmuir, 2019, 35, 8646-8657.

46 M. Massaro, P. Poma, C. G. Colletti, A. Barattucci, P. M. Bonaccorsi, G. Lazzara, G. Nicotra, F. Parisi, 
T. M. G. Salerno, C. Spinella and S. Riela, Appl. Clay Sci., 2020, 184, 105400.

47 K. Aschberger, H. J. Johnston, V. Stone, R. J. Aitken, S. M. Hankin, S. A. K. Peters, C. L. Tran and F. M. Christensen, Crit. Rev. Toxicol., 2010, 40, 759-790.

48 N. Kobayashi, H. Izumi and Y. Morimoto, J. Occup. Health, 2017, 59, 394-407.

49 W. Asghar, H. Shafiee, V. Velasco, V. R. Sah, S. Guo, R. El Assal, F. Inci, A. Rajagopalan, M. Jahangir, R. M. Anchan, G. L. Mutter, M. Ozkan, C. S. Ozkan and U. Demirci, Sci. Rep., 2016, 6, 30270.

50 Y. Cao and Y. Luo, Toxicol. Appl. Pharmacol., 2019, 385, 114801.

51 C. P. Firme 3rd and P. R. Bandaru, Nanomedicine, 2010, 6, 245-256.

52 D. Mohanta, S. Patnaik, S. Sood and N. Das, J. Pharm. Anal., 2019, 9, 293-300.

53 S. K. Prajapati, A. Malaiya, P. Kesharwani, D. Soni and A. Jain, Drug Chem. Toxicol., 2020, 1-16, DOI: 10.1080/ 01480545.2019.1709492..

54 M. Yang and M. Zhang, Front. Mater., 2019, 6, 225.

55 Y. Liu, Y. Zhao, B. Sun and C. Chen, Acc. Chem. Res., 2013, 46, 702-713.

56 A. J. Koivisto, A. B. Bluhme, K. I. Kling, A. S. Fonseca, E. Redant, F. Andrade, K. S. Hougaard, M. Krepker, O. Prinz Setter, E. Segal, A. Holländer, K. A. Jensen, U. Vogel and I. K. Koponen, NanoImpact, 2018, 10, 153160.

57 N. Gupta, S. M. Gupta and S. K. Sharma, Carbon Lett., 2019, 29, 419-447.

58 F. Yang, Q. Jiang, W. Xie and Y. Zhang, Chemosphere, 2017, 185, 162-170.

59 P. Yuan, P. D. Southon, Z. Liu, M. E. R. Green, J. M. Hook, S. J. Antill and C. J. Kepert, J. Phys. Chem. C, 2008, 112, 15742-15751.

60 T. Zhang, M. Tang, S. Zhang, Y. Hu, H. Li, T. Zhang, Y. Xue and Y. Pu, Int. J. Nanomed., 2017, 12, 1539-1554.

61 B. A. Kakade and V. K. Pillai, J. Phys. Chem. C, 2008, 112, 3183-3186.

62 K. K. Barfod, K. M. Bendtsen, T. Berthing, A. J. Koivisto, S. S. Poulsen, E. Segal, E. Verleysen, J. Mast, A. Hollander, K. A. Jensen, K. S. Hougaard and U. Vogel, Environ. Toxicol. Pharmacol., 2019, 73, 103266.

63 X. Wang, J. Gong, R. Rong, Z. Gui, T. Hu and X. Xu, J. Agric. Food Chem., 2018, 66, 2925-2933.

64 T. Hu, X. Wang, W. Tan, K. Nie and X. Xu, Environ. Sci. Pollut. Res., 2020, 17730-17737, DOI: 10.1007/s11356-02008314-1..

65 Y. Wu, J. Yang, H. Gao, Y. Shen, L. Jiang, C. Zhou, Y. Li, R.-R. He and M. Liu, ACS Appl. Nano Mater., 2018, 1, 595608.

66 J. H. Lim, S. H. Kim, I. C. Lee, C. Moon, S. H. Kim, D. H. Shin, H. C. Kim and J. C. Kim, Environ. Health Toxicol., 2011, 26, e2011006.

67 Z. Long, Y. Wu, H. Gao, J. Zhang, X. Ou, R. He and M. Liu, J. Mater. Chem. B, 2018, 6, 7204-7216.
68 G. I. Fakhrullina, F. S. Akhatova, Y. M. Lvov and R. F. Fakhrullin, Environ. Sci. Nano, 2015, 2, 54-59.

69 X. Zhao, Q. Wan, X. Fu, X. Meng, X. Ou, R. Zhong, Q. Zhou and M. Liu, ACS Sustainable Chem. Eng., 2019, 7, 18965-18975.

70 M. Kryuchkova, A. Danilushkina, Y. Lvov and R. Fakhrullin, Environ. Sci. Nano, 2016, 3, 442-452.

71 E. Haque and A. C. Ward, Nanomaterials, 2018, 8, 561.

72 P. Jackson, N. R. Jacobsen, A. Baun, R. Birkedal, D. Kühnel, K. A. Jensen, U. Vogel and H. Wallin, Chem. Cent. J., 2013, 7, 154.

73 N. Chatterjee, J. Yang, H. M. Kim, E. Jo, P. J. Kim, K. Choi and J. Choi, J. Toxicol. Environ. Health, Part A, 2014, 77, 1399-1408.

74 R. Abhinayaa, G. Jeevitha, D. Mangalaraj, N. Ponpandian and P. Meena, Appl. Clay Sci., 2019, 174, 57-68.

75 H. Choi, T. J. Stazak and C. D. Montemagno, J. Nanopart. Res., 2013, 15, 2008.

76 Y. Zhang, Y. Chen, H. Zhang, B. Zhang and J. Liu, J. Inorg. Biochem., 2013, 118, 59-64.

77 A. A. Taylor, G. M. Aron, G. W. Beall, N. Dharmasiri, Y. Zhang and R. J. McLean, Environ. Toxicol., 2014, 29, 961-968.

78 Listing of Specific Substances Affirmed as GRAS - Sec. 186.1256 Clay (kaolin). FDA, USA, 2018.

79 NanoPack web page, https://www.nanopack.eu/, (accessed 26 April, 2020).

80 S. Maisanaba, S. Pichardo, M. Puerto, D. GutierrezPraena, A. M. Camean and A. Jos, Environ. Res., 2015, 138, 233-254.

81 N. K. Verma, E. Moore, W. Blau, Y. Volkov and R. P. Babu, J. Nanopart. Res., 2012, 14, 1137.

82 V. Vergaro, E. Abdullayev, Y. M. Lvov, A. Zeitoun, R. Cingolani, R. Rinaldi and S. Leporatti, Biomacromolecules, 2010, 11, 820-826.

83 X. Lai, M. Agarwal, Y. M. Lvov, C. Pachpande, K. Varahramyan and F. A. Witzmann, J. Appl. Toxicol., 2013, 33, 1316-1329.

84 F. R. Ahmed, M. H. Shoaib, M. Azhar, S. H. Um, R. I. Yousuf, S. Hashmi and A. Dar, Colloids Surf., B, 2015, 135, 50-55.

85 L. B. Williams, D. W. Metge, D. D. Eberl, R. W. Harvey, A. G. Turner, P. Prapaipong and A. T. Poret-Peterson, Environ. Sci. Technol., 2011, 45, 3768-3773.

86 K. D. Morrison, R. Misra and L. B. Williams, Sci. Rep., 2016, 6, 19043.

87 A. Panchal, L. T. Swientoniewski, M. Omarova, T. Yu, D. Zhang, D. A. Blake, V. John and Y. M. Lvov, Colloids Surf., B, 2018, 164, 27-33.

88 S. A. Konnova, Y. M. Lvov and R. F. Fakhrullin, Clay Miner., 2016, 51, 429-433.

89 S. A. Konnova, I. R. Sharipova, T. A. Demina, Y. N. Osin, D. R. Yarullina, O. N. Ilinskaya, Y. M. Lvov and R. F. Fakhrullin, Chem. Commun., 2013, 49, 4208-4208.

90 Y. Zhang, R. Gao, M. Liu, C. Yan and A. Shan, Arch. Anim. Nutr., 2014, 68, 320-335. 
91 Y. Zhang, R. Gao, M. Liu, B. Shi, A. Shan and B. Cheng, Theriogenology, 2015, 83, 932-941.

92 M. D. Paola, A. Quarta, P. Pisani, F. Conversano, E. A. Sbenaglia, S. Leporatti, G. Gigli and S. Casciaro, IEEE Trans. Nanotechnol., 2016, 15, 770-774.

93 M. Liu, Z. Jia, D. Jia and C. Zhou, Prog. Polym. Sci., 2014, 39, 1498-1525.

94 M. Liu, Y. Zhang, C. Wu, S. Xiong and C. Zhou, Int. J. Biol. Macromol., 2012, 51, 566-575.

95 E. Rozhina, A. Panchal, F. Akhatova, Y. Lvov and R. Fakhrullin, Appl. Clay Sci., 2020, 185, 105371.

96 A. Sánchez-Fernández, L. Pena-Paras, R. Vidaltamayo, R. Cue-Sampedro, A. Mendoza-Martinez, V. C. ZomosaSignoret, A. M. Rivas-Estilla and P. Riojas, Materials, 2014, 7, 7770-7780.

97 R. Abhinayaa, G. Jeevitha, D. Mangalaraj, N. Ponpandian, K. Vidhya and J. Angayarkanni, Colloids Surf., B, 2018, 169, 395-403.

98 H. He, D. Yang, P. Yuan, W. Shen and R. L. Frost, J. Colloid Interface Sci., 2006, 297, 235-243.

99 Y. Liu and J. Tay, Water Res., 2002, 36, 1653-1665.

100 A. Alimova, A. Katz, N. Steiner, E. Rudolph, H. Wei, J. C. Steiner and P. Gottlieb, Clays Clay Miner., 2009, 57, 205-212.

101 A. Alimova, G. L. Coté, K. Block, A. V. Priezzhev, E. Rudolph, A. Katz, J. C. Steiner, P. Gottlieb and R. R. Alfano, presented in part at the Optical Diagnostics and Sensing VI, 2006.

102 Q. Huang, H. Wu, P. Cai, J. B. Fein and W. Chen, Sci. Rep., 2015, 5, 16857.

103 M. Barr, J. Am. Pharm. Assoc., 1957, 46, 490-492.

104 A. Partovinia and M. Koosha, eXPRESS Polym. Lett., 2019, 13, 484-499.

105 T. Yu, L. T. Swientoniewski, M. Omarova, M. C. Li, I. I Negulescu, N. Jiang, O. A. Darvish, A. Panchal, D. A. Blake, Q. Wu, Y. M. Lvov, V. T. John and D. Zhang, ACS Appl. Mater. Interfaces, 2019, 11, 2794427953.

106 A. Panchal, N. Rahman, S. Konnova, R. Fakhrullin, D. Zhang, D. Blake, V. John, E. Ivanov and Y. Lvov, ACS Appl. Nano Mater., 2019, 3, 1263-1271.

107 A. Stavitskaya, S. Batasheva, V. Vinokurov, G. Fakhrullina, V. Sangarov, Y. Lvov and R. Fakhrullin, Nanomaterials, 2019, 9, 708.

108 B. Čalija, J. Milić, N. Milašinović, A. Daković, K. Trifković, J. Stojanović and D. Krajišnik, J. Appl. Polym. Sci., 2019, 137, 48406.

109 W. Duan, N. Wang, W. Xiao, Y. Zhao and Y. Zheng, J. Mol. Liq., 2018, 269, 874-881.

110 D. Rawtani, G. Pandey, M. Tharmavaram, P. Pathak, S. Akkireddy and Y. K. Agrawal, Appl. Clay Sci., 2017, 150, 293-302.

111 Q. Pan, N. Li, Y. Hong, H. Tang, Z. Zheng, S. Weng, Y. Zheng and L. Huang, RSC Adv., 2017, 7, 21352-21359.

112 W. Jiang, P. Chang, Y. Tsai and Z. Li, Microporous Mesoporous Mater., 2016, 220, 298-307.
113 W. Wei, E. Abdullayev, A. Hollister, D. Mills and Y. M. Lvov, Macromol. Mater. Eng., 2012, 297, 645-653.

114 Y. Wu, Y. Yang, H. Liu, X. Yao, F. Leng, Y. Chen, W. Tian, C. Yu, B. Zhang, C. Fan, J. Li and P. Huang, RSC Adv., 2017, 7, 18917-18925.

115 W. Wei, R. Minullina, E. Abdullayev, R. Fakhrullin, D. Mills and Y. Lvov, RSC Adv., 2014, 4, 488-494.

116 M. Krepker, O. Prinz-Setter, R. Shemesh, A. Vaxman, D. Alperstein and E. Segal, Polymers, 2018, 10, 79.

117 M. Krepker, R. Shemesh, Y. Danin Poleg, Y. Kashi, A. Vaxman and E. Segal, Food Control, 2017, 76, 117-126.

118 R. Shemesh, M. Krepker, N. Nitzan, A. Vaxman and E. Segal, Postharvest Biol. Technol., 2016, 118, 175-182.

119 R. Shemesh, M. Krepker, M. Natan, Y. Danin-Poleg, E. Banin, Y. Kashi, N. Nitzan, A. Vaxman and E. Segal, RSC Adv., 2015, 5, 87108-87117.

120 J. F. Boelter, A. Brandelli, S. M. M. Meira, G. Göethel and S. C. Garcia, Appl. Clay Sci., 2020, 188, 105490.

121 L. Ghezzi, A. Spepi, M. Agnolucci, C. Cristani, M. Giovannetti, M. R. Tiné and C. Duce, Appl. Clay Sci., 2018, 160, 88-94.

122 G. Fakhrullina, E. Khakimova, F. Akhatova, G. Lazzara, F. Parisi and R. Fakhrullin, ACS Appl. Mater. Interfaces, 2019, 11, 23050-23064.

123 R. Abhinayaa and D. Mangalaraj, Mater. Today: Proc., 2019, 18, 1709-1715.

124 Q. Zhao, C. Liu, J. Liu and Y. Zhang, RSC Adv., 2015, 5, 38646-38653.

125 Y. E. Bulbul, M. Okur, F. Demirtas-Korkmaz and N. Dilsiz, Appl. Clay Sci., 2020, 186, 105430.

126 J. Xue, Y. Niu, M. Gong, R. Shi, D. Chen, L. Zhang and Y. Lvov, ACS Nano, 2015, 9, 1600-1612.

127 S. Kalagi, S. A. Feitosa, E. A. Munchow, V. M. Martins, A. E. Karczewski, N. B. Cook, K. Diefenderfer, G. J. Eckert, S. Geraldeli and M. C. Bottino, Dent. Mater., 2020, 36, 687-697.

128 J. C. Monteiro, I. M. Garcia, V. C. B. Leitune, F. Visioli, G. S. Balbinot, S. M. W. Samuel, I. Makeeva, F. M. Collares and S. Sauro, Dent. Mater., 2019, 35, 789796.

129 T. Barot, D. Rawtani, P. Kulkarni, C. M. Hussain and S. Akkireddy, J. Mech. Behav. Biomed. Mater., 2020, 104, 103675.

130 K. Huang, Q. Ou, Y. Xie, X. Chen, Y. Fang, C. Huang, Y. Wang, Z. Gu and J. Wu, ACS Biomater. Sci. Eng., 2019, 5, 4037-4047.

131 R. Shi, Y. Niu, M. Gong, J. Ye, W. Tian and L. Zhang, Mater. Sci. Eng., C, 2018, 87, 128-138.

132 M. Krepker, C. Zhang, N. Nitzan, O. Prinz Setter, N. Massad-Ivanir, A. Olah, E. Baer and E. Segal, Polymers, 2018, 10, 864.

133 Y. Horikawa, T. Terai and H. Ogura, Soil Sci. Plant Nutr., 1979, 25, 357-364.

134 H. Ahn, J. U. Rehman, T. Kim, M. S. Oh, H. Y. Yoon, C. Kim, Y. Lee, S. G. Shin and J. R. Jeon, Water Res., 2020, 186, 116380. 
135 D. Tan, H. Zhang, S. Sun, F. Dong, H. Sun and B. Li, Appl. Clay Sci., 2019, 177, 37-42.

136 M. Massaro, A. Campofelice, C. G. Colletti, G. Lazzara, R. Noto and S. Riela, Appl. Clay Sci., 2018, 160, 186-192.

137 X. Yue, X. Yang, H. Li, R. Zhang and D. Qin, Quaternary Ammonium Compounds-Modified Halloysite and Its Antifungal Performance, in Physics and Techniques of Ceramic and Polymeric Materials, Proceedings in Physics, Springer, 2019, ch. 14, vol. 216, pp. 121-131.

138 X. Jin, R. Zhang, M. Su, H. Li, X. Yue, D. Qin and Z. Jiang, RSC Adv., 2019, 9, 42062-42070.

139 J. Xue, Z. Guan, J. Lin, C. Cai, W. Zhang and X. Jiang, Small, 2017, 13, 1604214.

140 N. B. Shah, J. Dong and J. C. Bischof, Mol. Pharm., 2011, 8, 176-184.

141 B. Kong, J. H. Seog, L. M. Graham and S. B. Lee, Nanomedicine, 2011, 6, 929-941.

142 V. Raffa, G. Ciofani, O. Vittorio, C. Riggio and A. Cuschieri, Nanomedicine, 2010, 5, 89-97.

143 K. Rawat, S. Agarwal, A. Tyagi, A. K. Verma and H. B. Bohidar, Appl. Biochem. Biotechnol., 2014, 174, 936-944.

144 H. Liu, Z. Wang, S. Liu, X. Yao, Y. Chen, S. Shen, Y. Wu and W. Tian, J. Mater. Sci., 2018, 54, 693-704.

145 M. R. Dzamukova, E. A. Naumenko, Y. M. Lvov and R. F. Fakhrullin, Sci. Rep., 2015, 5, 10560.

146 J. Liao, S. Peng, M. Long, Y. Zhang, H. Yang, Y. Zhang and J. Huang, Colloids Surf., A, 2019, 586, 124242.

147 E. Tarasova, E. Naumenko, E. Rozhina, F. Akhatova and R. Fakhrullin, Appl. Clay Sci., 2019, 169, 21-30.

148 A. D. Hughes and M. R. King, Langmuir, 2010, 26, 1215512164.

149 A. D. Hughes, J. Mattison, L. T. Western, J. D. Powderly, B. T. Greene and M. R. King, Clin. Chem., 2012, 58, 846-853.

150 M. J. Mitchell, C. S. Chen, V. Ponmudi, A. D. Hughes and M. R. King, J. Controlled Release, 2012, 160, 609-617.

151 M. J. Mitchell, C. A. Castellanos and M. R. King, Biomaterials, 2015, 56, 179-186.

152 M. Liu, R. He, J. Yang, W. Zhao and C. Zhou, ACS Appl. Mater. Interfaces, 2016, 8, 7709-7719.

153 R. He, M. Liu, Y. Shen, Z. Long and C. Zhou, J. Mater. Chem. B, 2017, 5, 1712-1723.

154 R. He, M. Liu, Y. Shen, R. Liang, W. Liu and C. Zhou, Mater. Sci. Eng., C, 2018, 85, 170-181.

155 X. Zhao, C. Zhou, Y. Lvov and M. Liu, Small, 2019, 15, e1900357.

156 M. Kryuchkova, S. Batasheva, E. Naumenko, E. Rozhina, F. Akhatova, A. Panchal, Y. Lvov and R. Fakhrullin, Appl. Clay Sci., 2020, 195, 105707.

157 F. Wu, J. Zheng, Z. Li and M. Liu, Chem. Eng. J., 2019, 359, 672-683.

158 P. Y. Wang, H. T. Yu and W. B. Tsai, Biotechnol. Bioeng., 2010, 106, 285-294.

159 D. Mills and Y. M. Lvov, US Pat., 9192912B1, 2015.

160 F. W. Degrazia, V. C. B. Leitune, A. S. Takimi, F. M. Collares and S. Sauro, Dent. Mater., 2016, 32, 11331143.
161 N. Kerdsakundee, W. Li, J. P. Martins, Z. Liu, F. Zhang, M. Kemell, A. Correia, Y. Ding, M. Airavaara, J. Hirvonen, R. Wiwattanapatapee and H. A. Santos, Adv. Healthcare Mater., 2017, 6, 1700629.

162 M. C. Bottino, G. Batarseh, J. Palasuk, M. S. Alkatheeri, L. J. Windsor and J. A. Platt, Dent. Mater., 2013, 29, 11581165.

163 U. Jammalamadaka, K. Tappa, J. A. Weisman, J. C. Nicholson and D. K. Mills, Nanotechnol., Sci. Appl., 2017, 10, 105-114.

164 E. A. Naumenko, I. D. Guryanov, R. Yendluri, Y. M. Lvov and R. F. Fakhrullin, Nanoscale, 2016, 8, 7257-7271.

165 M. Liu, C. Wu, Y. Jiao, S. Xiong and C. Zhou, J. Mater. Chem. B, 2013, 1, 2078-2089.

166 B. Huang, M. Liu, Z. Long, Y. Shen and C. Zhou, Mater. Sci. Eng., C, 2017, 70, 303-310.

167 M. A. Bonifacio, P. Gentile, A. M. Ferreira, S. Cometa and E. De Giglio, Carbohydr. Polym., 2017, 163, 280-291.

168 E. Torres, V. Fombuena, A. Valles-Lluch and T. Ellingham, Mater. Sci. Eng., C, 2017, 75, 418-424.

169 G. Lazzara, S. Riela and R. F. Fakhrullin, Ther. Delivery, 2017, 8, 633-646.

170 Z. Long, J. Zhang, Y. Shen, C. Zhou and M. Liu, Mater. Sci. Eng., C, 2017, 81, 224-235.

171 Z. Long, Y. P. Wu, H. Y. Gao, Y. F. Li, R. R. He and M. Liu, Bioconjugate Chem., 2018, 29, 2606-2618.

172 M. Massaro, G. Barone, G. Biddeci, G. Cavallaro, F. Di Blasi, G. Lazzara, G. Nicotra, C. Spinella, G. Spinelli and S. Riela, J. Colloid Interface Sci., 2019, 552, 236-246.

173 J. Liu, Y. Zhang, Q. Zeng, H. Zeng, X. Liu, P. Wu, H. Xie, L. He, Z. Long, X. Lu, M. Xiao, Y. Zhu, H. Bo and K. Cao, Sci. Adv., 2019, 5, eaaw6499.

174 S. Riela, M. Massaro, C. G. Colletti, A. Bommarito, C. Giordano, S. Milioto, R. Noto, P. Poma and G. Lazzara, Int. J. Pharm., 2014, 475, 613-623.

175 R. Yendluri, Y. Lvov, M. M. de Villiers, V. Vinokurov, E. Naumenko, E. Tarasova and R. Fakhrullin, J. Pharm. Sci., 2017, 106, 3131-3139.

176 P. Dramou, M. Fizir, A. Taleb, A. Itatahine, N. S. Dahiru, Y. A. Mehdi, L. Wei, J. Zhang and H. He, Carbohydr. Polym., 2018, 197, 117-127.

177 Y. Hu, J. Chen, X. Li, Y. Sun, S. Huang, Y. Li, H. Liu, J. Xu and S. Zhong, Nanotechnology, 2017, 28, 375101.

178 L. Y. Li, Y. M. Zhou, R. Y. Gao, X. C. Liu, H. H. Du, J. L. Zhang, X. C. Ai, J. P. Zhang, L. M. Fu and L. H. Skibsted, Biomaterials, 2019, 190-191, 86-96.

179 J. Zhang, X. Luo, Y. P. Wu, F. Wu, Y. F. Li, R. R. He and M. Liu, ACS Appl. Mater. Interfaces, 2019, 11, 3690-3703.

180 X. Luo, J. Zhang, Y. Wu, X. Yang, X. Kuang, W. Li, Y. Li, R. He and M. Liu, ACS Biomater. Sci. Eng., 2020, 6, 3361-3374.

181 R. Rong, X. Xu, S. Zhu, B. Li, X. Wang and K. Tang, Chem. Eng. J., 2016, 291, 20-29.

182 C. V. Chrysikopoulos and V. I. Syngouna, Colloids Surf., B, 2012, 92, 74-83.

183 G. Berg, Methods For Recovering Viruses From The Environment, CRC Press, Boca Raton, 1987. 